Portland State University

PDXScholar

2005

\title{
"We want smokestacks and not swamps" : filling in Portland's Guild's Lake, 1906-1925
}

\author{
Kathleen D. Tucker \\ Portland State University
}

Follow this and additional works at: https://pdxscholar.library.pdx.edu/open_access_etds

Part of the History Commons, and the Urban Studies and Planning Commons Let us know how access to this document benefits you.

\section{Recommended Citation}

Tucker, Kathleen D., "'We want smokestacks and not swamps" : filling in Portland's Guild's Lake, 1906-1925" (2005). Dissertations and Theses. Paper 3557.

https://doi.org/10.15760/etd.5439

This Thesis is brought to you for free and open access. It has been accepted for inclusion in Dissertations and Theses by an authorized administrator of PDXScholar. Please contact us if we can make this document more accessible: pdxscholar@pdx.edu. 


\section{THESIS APPROVAL}

The abstract and thesis of Kathleen D. Tucker for the Master of Arts in History were presented November 1,2005, and accepted by the thesis committee and the department.

COMMITTEE APPROVALS:

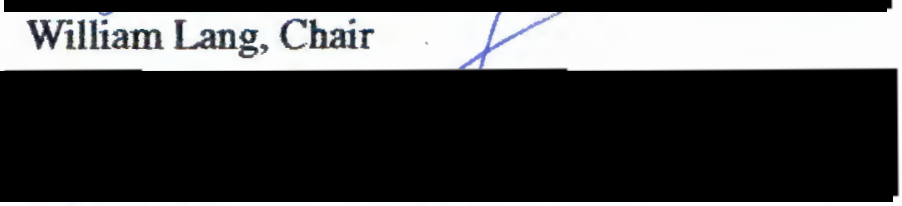

Katrine Barber

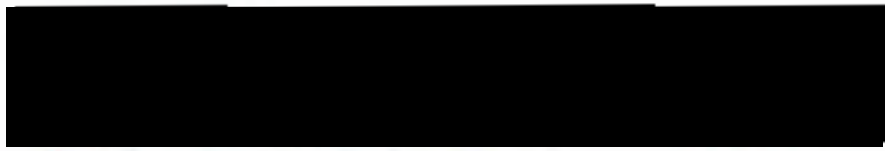

Carl Abbott

Representative of the Office of Graduate Studies

DEPARTMENT APPROVAL

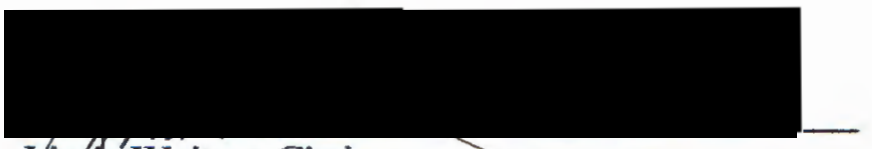

Leinda Walton, Chair

Department of History 


\section{ABSTRACT}

An abstract of the thesis of Kathleen D. Tucker for the Master of Arts in Fistory presented November 1, 2005.

Title: "We Want Smokestacks and Not Swamps:" Filling In Portland's Guild's Lake, 1906-1925

Between 1905 and 1926, developers, real estate speculators, and the Port of Portland filled in Guild's Lake, a riparian marsh that had been the location for Portland's 1905 Lewis and Clark Exposition and Oriental Fair. There were two phases in the filling process. The first phase, which began before the fair ended and lasted until 1914, involved developers using high-pressured hydraulic hoses to sluice soil from nearby hills into the lake. Their primary goal was to terrace the hillside to create a high-end view neighborhood; Guild's Lake was a convenient "dump" for the gravel and dirt. During the second phase, from 1919 to 1926. Portland's elite business leaders teamed up with the city and the Port of Portland to use dredge spoils from a Willamette River channel change and deepening for a more comprehensive filling operation at Guild's Lake. Although city and citizen planning efforts to establish a publicly-owned industrial area at Guild's Lake failed, private landowners at Guild's Lake negotiated with the Port of Portland to fill the lake. 
People have long been filling wetlands to create space for city growth, so this development was not unusual. This thesis looks at Guild's Lake as a case study of landscape creation in an urban environment. This study asks questions about the interaction between culture and environment. How did contemporary perceptions about the environment and wetlands affect how people viewed Guild's Lake? How did changing social values and trends frame action? How did environment and natural landforms shape or limit possibilities?

In creating a new landscape at Guild's Lake, people worked to build a space that would bring economic benefits and fit perceived social needs. While the wealthy developers argued that the changes would benefit all Portlanders, they were primarily motivated with possibilities for personal financial gain. National planning trends influenced their actions, and changed developers approach between the first and second phases of the filling project. The environment played a role by influencing how humans looked at the landscape and how they worked to change it. 
("WE WANT SMOKESTACKS AND NOT SWAMPS:"

FILLING IN PORTLAND'S GUILD'S LAKE, 1906-1925

by

KATHLEEN D. TUCKER

A thesis submitted in partial fulfillment of the requirements for the degree of

\section{MASTER OF ARTS \\ in \\ HISTORY}

Portland State University

2005 


\section{ACKNOWLEDGEMENTS}

I would like to first acknowledge my students, who inspired me to take on this topic. They built a web site about the history of land use at Guild's Lake, which can be viewed at http://www.history.pdx.edu/guildslake/. They are: Toni Anderson, Mo Barghouty, Matt Bear, Ian Brown, Karin Dibling, Scott Garrison, Debra Garwood, Shauna Hanson, Alison Hubbard, Max Holfert, Jared Johnson, Lauren Joost, Matt Krzesniak, Sarah Lambert, Lindsey Lang, Bryan Lassner, Katherine Lawrence, Zachary Lewis, Julie Martin, Scott Mcconnell, Joel Miller, Margie Milne, Jason Newell, Jackie Patel, Stephen Phillip; Matt Ralphe, Caroline Reeve, Sarah Riddle, Kym Riffe, Andrew Riggle, Bill Roberts, Caitlin Sanders, Christa Schneider, Wayne Sehman, Mark Smith, Meghan Stone, Tam Tran, Ruby Veniegas, Robin Warr, Gayle Webb, and Joe Whitton.

I would also like to thank my advisor, William Lang, and also the many librarians and archivists that assisted me, including Diana Banning and Brian Johnson at the City of Portland Archives, and the staff librarians at the Minnesota Historical Society and the Oregon Historical Society.

I would also like to thank my husband, Harvey Golden, for making it possible for me to finish this thesis. 


\section{TABLE OF CONTENTS}

Acknowledgements $i$

List of Figures $\quad$ iii

Introduction

$\begin{array}{ll}\text { Creating a Landscape } & 1\end{array}$

Chapter One

Perceptions of Nature: Negative Views of Wetlands

Affect Land Use

Chapter Two

Blasting the Hills: Developers Use Hydraulic Power to Create Space

Chapter Three

Planning an Industrial District: The Port of Portland and Landowners Cooperate

60

Conclusion

Culture and Environment Build Landscapes

92

References

101 


\section{FIGURES}

Figure 1: St. Helens Road in 1891

Figure 2: Garbage Dump

Figure 3: Illustration of Pence's Operation

Figure 4: 1909 Map

Figure 5: Filling in 1925 


\section{Introduction: Creating a Landscape}

People and their environments intertwine through time to create places that are not wholly human or natural, but a combination of both. The balance of influence in that interactive relationship changes depending on many cultural and physical factors. Historically, it seems that some cultures have been more responsive to the realities of their physical environments than others. In North America most native people traditionally organized their lives and cultures around the constraints of their natural environment, but European immigrants often used technology to radically alter environments to fit contemporary beliefs and values. Those efforts have had varying degrees of success, and often created places that are an amalgamation of human and natural elements. In his book, The Organic Machine, Richard White explored how humans altered the Columbia River, primarily by building many large dams on the river and its tributaries. The result, as his title suggests, is a mixture of human and natural elements. Nature is altered, but not gone. ${ }^{3}$ Alterations to landscapes sometimes result with the apparent disappearance of all pre-existing natural elements. World wide, city builders have drained and buried wetlands and waterways for thousands of years. The human impetus to shape landscapes has been especially intense in urban areas, where people have focused their populations and economic interests. Fifth-century Venetians built their city in the middle of a marshy lagoon and in the eighteenth century French colonists established New Orleans in the middle of a large, swampy river delta. In Portland, beginning in the late nineteenth century,

\footnotetext{
'Richard White, The Organic Machine. New York: Hill and Wang, 1995, ix-xi.
} 
people buried numerous streams, sloughs, and marshy lakes - including Guild's Lake, one of the largest wetlands near downtown. At Guild's Lake, nature participated in landscape creation largely by informing and directing human actions. People”s perceptions about the environment and the city's geologic contours framed their visions and plans. Furthermore, the natural realities of water and watery places induced Guild's Lake developers to act communally, which emphasized intra-cultural conflicts. People believed changing the landscape would be beneficial, but tensions brewed over whether private individuals or the larger community would reap those benefits. While nature helped guide the course of human alterations, cultural beliefs and values dominated landscape formation at Guild's Lake. The result was a radically altered environment and urban space.

Located in what is today the Northwest Industrial District, Guild's Lake was an approximately 250-acre riparian marsh adjacent to the Willamette River. Maps and photographs from the late nineteenth and early twentieth centuries reveal the lake's crescent shape, which geologists conclude was formed by a meandering portion of the Willamette River cut off by changes in sediment deposits and river flow. The lake remained connected to the river by an underground water table, and it rose and fell with the seasonal fluctuations of the Willamette. ${ }^{2}$ While the Multnomah band of the Chinookan people might have valued Guild's Lake for the resources that such wetlands offered - camas and wapato - Portland city builders sought different

\footnotetext{
${ }^{2}$ The groundwater under Portland's west side is connected to the Troutdale gravel aquifer. Foundation Engineering, Inc., "Preliminary Geologic Assessment," Westside Combined Sewer Overflow Tumel Project, City of Portland, July 17, 2000, 10-11.
} 
resources, including real estate and the possibility of new land for city growth.

Between 1905 and 1925, developers filled in Guild's Lake by using giant mining hoses to sluice away nearby hillsides and also by dredging the Willamette River.

Today, city planning protects the area for industrial use, and little remains to indicate that a wetland once existed there. ${ }^{3}$

Human culture and history are reflected in landscapes. To define "landscape," geographer Donald Meinig compares the concept to environment and place.

Environment is closely attached to us, "directly part of our organic being," Meinig argues, while place is a human conception dependent upon personal experience. In contrast, landscape is almost a canvas showing multiple layers of human use. Meinig writes that geographers:

Regard all landscapes as symbolic, as expressions of cultural values, social behavior, and individual actions worked upon particular localities over a span of time. ${ }^{4}$

In 1925, the influential geographer Carl Sauer helped expand geographers' reach into landscape studies, cultural geography, and historical geography with his essay ${ }_{\text {"cT }}$ The Morphology of Landscape." He argued that landscape was made up of both physical and cultural elements, and that humans were actually geomorphologic agents:

The works of man express themselves in the cultural landscape. There may be a succession of these landscapes with a succession of cultures. They are derived in each case from the natural landscape, man

\footnotetext{
${ }^{3}$ Portland Bureau of Planning, "Adopted Guild's Lake Industrial Sanctuary Plan," 2005, http://www.portlandonline.com/planning/index.cfm?c=34289 (6 January 2005).

${ }^{4}$ D.W Meinig, The Interpretation of Ordinary Landscapes: Geographical Essays. New York and Oxford: Oxford University Press, 1979, 3-6.
} 
expressing his place in nature as a distinct agent of modification. $^{5}$

Landscape is not static. Just as successive peoples may make a series of modifications to an area, reflecting their different cultures, multiple generations of the same culture might reshape a landscape according to contemporary visions. Furthermore, those changes may tell stories of conflicting goals and values within generations and cultures. Humans shape landscapes, but it is not a one-sided dance of cause and effect - nature also contributes to landscapes and affects human cultures.

Physical nature is not an inert stage for human activity. In their book, People, Land and Time, geographers Peter Atkins, Ian Simmons, and Brian Roberts argue:

That landscapes are not passive objects that lie silently waiting for successive human imprints. In a sense they are active participants in channeling socio-economic evolution because they set the physical and psychological constraints within which people must act. ${ }^{6}$

Environmental historians tread into the realm of geographers in exploning the extent of how human actions are shaped by the environment and natural forces. As Dan Flores defines the issue, the question of how "humans not only alter environments but also adapt to them" is central to "questions of environmental history."7 Culture may frame the human perceptions of the environment, and their relationship to it, but the physical form and realities of an environment limit human choices and affect attempts to alter a

\footnotetext{
${ }^{5}$ Carl Sauer, "The Morphology of Landscape." Land and Life: A Selection from the Writings of Carl Ortwin Sauer, ed. John Leighly. Berkeley and Los Angeles: University of Califomia Press, 1965, 315 350.

"Peter Atkins, Ian Simmons and Brian Roberts, People, Land and Time: an historical introduction to the relations between landscape, culture and environment. London and New York: Amold, 1998, 224. ${ }^{7}$ Dan Flores, "Place: An Argument for Bioregional History" in Nortinest Lands, Northwest Peoples: Readings in Envirommental History. eds. Dale D. Goble and Paul W. Hirt. Seatle and London: University of Washington Press, 1999, 31-50.
} 
specific place or geologic entity, such as a river. In cities, where dense human populations intently focus on applying technology to alter hills, ravines, rivers, and wetlands, the interactions between culture, or human perceptions and wants, and physical nature can be complex. ${ }^{8}$ While cultural factors may dominate in an urban landscape, nature remains a force.

Human conceptualization of the environment influences landscape formation. In western societies, classical philosophers debated whether or not nature was created for human use. The Euro-American settlers who came to Portland brought to their new home the Christian belief that humans were separate from nature. In Ecological Revolutions: Nature, Gender, and Science in New England, Carolyn Merchant contends that while pre-Christian Europeans and Native Americans saw themselves as a part of the natural world, Christian theology encouraged people to see nature as God's gift for their use, facilitating the commodification of nature and the growth of capitalism. ${ }^{9}$ Not only were the fruits of the land available for collection and sale, but the land itself became an item for trade and profit. This cultural practice of allowing private ownership of parcels of the earth may raise inherent conflicts about who benefits. In Property and Persuasion, Carol Rose contends that there is a gap between the human relationship to land as an environment and the conceptualizations of the land as a commodity.

\footnotetext{
${ }^{8}$ Andrew Hurley explores some of these types of interactions in Common Fields: An Envirommental History of St. Louis. ed. St. Louis: Missouri Historical Society Press, 1997, 1.

${ }^{9}$ Daniel Botkin, Discordant Harmonies: A New Ecology for the Twenty-first Centwry. New York and Oxford: Oxford University Press, 1990, 87; Carolyn Merchant, Ecological Revolutions: Nature, Gender, and Science in New England. Chapel Hill and London: The University of North Carolina Press, $1989,20-23$.
} 
(If) property regimes cannot get over the self-interest problem without imparting some sense of a common good, then narratives, stories, and rhetorical devices may be essential in persuading people of that common good. $^{10}$

Additionally, human ideas about the economic value of specific ecological entities are factors in landscape creation. Historically, Americans have believed that wetlands had no redeeming value. William Cronon explains that bogs, marshes, and swamps have been historically viewed as "useless, worthless, bothersome places that blocked travel, bred mosquitoes, frustrated settlement, and generally threw up the most annoying and inconvenient barriers to human progress." environments and then use their assumptions to inform actions.

Culture also affects how people read a specific places. City builders viewed landforms through a cultural prism of social, economic, and political values. The physical contours of land suggested usage to developers and also limited possibilities. In Portland, where the Willamette River and West Hills spatially limited the city's downtown, realtors had long viewed the highlands above downtown and Guild's Lake

\footnotetext{
${ }^{10}$ Carol M. Rose, Property and Persuasion: Exsays on the History, Theory, and Rhetoric of Ownership. Boulder, San Francisco, and Oxford: Westview Press, 1994, 6; Another interesting book about issues of property and nature is Theodore Stienberg's Stide Mountain, or the Folly of Owning Nature. Berkeley, Los Angeles, and London: University of California Press, 1995.

${ }^{11}$ Cronon also points out that a "cultural blind spot" about wetlands has contributed to a lamentable scarcity of wetland studies in American environmental history. He argues that the few scholars who have examined American wetlands have not closely studied the "crucial landscape-transforming process" of draining or filling those wetlands. Even scarcer are works examining those processes within cities. William Cronon, "Foreword: On The Margins" in Nancy Langston"s Where Land and Water Meet: $A$ Western Landscape Transformed. Seatile and London: University of Washington Press, 2003 , ix-xi.; Ann Vileisis provides a good overview of American views about wetlands and their general treatment of them, but focuses primarily on wetlands drained for farming purposes. Ann Vileisis. Discovering the Unknown Landscape: A History of America's Wetlands. Washington D.C. and Covelo, Calif.: Island Press, 1997; In looking at urban areas, Brian Hudson's Cities on the Shore: The Urbon Littoral Frontier offers a very useful, world-wide overview of the process of urban "reclamation" for development purposes. Brian J. Hudson, Cities on the Shore: The Urban Lintoral Frontier. London: Pinter, 1996.
} 
as appropriate and lucrative locations for upscale housing. They saw the city's flat wetlands as ideal for industry. Andrew Hurley, who has studied the environmental history of St. Louis, finds that developers often used natural land formations to separate city sections:

The spatial distribution of economic functions and population groups within cities have followed the physical contours of the landscape. . . . wealthy districts [are] often found on high ground where the air circulates rapidly, visitors are the most pleasing, and the ground is best protected from unforeseen floods. Likewise, the factory districts often occupy land adjacent to rivers and harbors, where manufacturers have enjoyed easy access to water for transportation disposal, and power. ${ }^{12}$

The geologic formations, and cultural opinions about them, determined the range of human choices about how to organize city landscapes.

People also were dependent on environmental factors. American city dwellers have often used new technologies to alter nature, only later to discover how their own well-being was connected to the environment. At the turn of the nineteenth and twentieth centuries, the advent of wide-spread indoor plumbing collided with misconceptions about the value of clean waterways and diseases to create an urban health crisis nationwide. In his book, In Search of the Ultimate Sink: Urban Pollution in Historical Perspective, urban environmental historian Joel Tarr explores many health and pollution issues within cities that arose with new technologies. Modern plumbing brought an indoor water supply that overloaded household cesspools, and human waste polluted groundwater and nearby streams. Many homeowners dealt with

\footnotetext{
${ }^{12}$ Hurley, 2.
} 
the problem by directly piping their waste to the nearest waterway, believing that rivers were self-cleaning and that it was sufficient to literally send the problem downstream. Human waste polluted drinking water and caused diseases such as typhoid fever within cities and in down river communities. While city health experts and engineers realized the issue had to be dealt with - that indoor plumbing and human waste had created an environmental hazard - cultural values framed their responses. Even after people understood how disease spread, many city officials applied a "cost-benefit framework" to the issue and continued piping waste into rivers instead of building expensive sewage treatment plants. Downstream cities had to filter and chlorinate water supplies. Eventually, health issues and recreation values forced cities to deal with the effects of human sewage in waterways. Even so, some municipalities - such as Portland and Pittsburgh - did not construct treatment plants until the 1950 s. ${ }^{13}$

Water's fluidity makes pollution hard to confine, and it also defies human efforts to compartmentalize property development. At Guild's Lake, Portland land speculators were eager to fill in the marsh and profit by selling the newly created land, but their determination met some natural resistance that affected how people proceeded with landscape alteration. Wetlands and submerged lands, such as shallow river edges and coastlines, present a special challenge to developers. Water crosses property lines, and human attempts to eliminate it from a particular land parcel face natural and social obstacles. In Discovering the Unknown Landscape, Ann Vileisis

\footnotetext{
${ }^{13}$ Joel Tarr, In search of the Ultimate Sink: Urban Pollution in Historical Perspective. Akron: University of Akron Press, 1996, 41-155.
} 
finds that Americans often "misunderstand the essentially liquid nature of wetland landscapes . . if a wetland is drained or filled, more run off will flow downstream, and neighbors basements may flood."14 Water was not cooperative and it made a mockery of the straight boundary lines of property at Guild's Lake. It seasonally flooded and receded across property lines, following underground water tables that brought runoff from the hillsides and overflow waters from the Willamette River. Vileisis argues that no one landowner could successfully drain or dike a portion of a swamp or marsh. ${ }^{15}$ Property owners had to cooperate in large-scale projects that involved collective choices about labor and technology, the cost and source of landfill material, and how to create infrastructure such as sewers and streets. This illuminated conflicting and evolving cultural values and goals.

At Guild's Lake, the need to work communally meant that people discussed and debated development plans. Tension between the private gain of speculators and the public good of the community wove a constant thread through the history of the area -- from the beginning of the twentieth century, when Portlanders considered making the area into a city park, until present-day conflicts about preserving the landscape for industrial use. Collective action involved both private and public planning and financing. In community discussions, proponents of various plans often obscured conflicts of interest and personal economic motives by promoting the landscape change as beneficial to the general public. In Cities on the Shore, Brian Hudson contends that this was a common tactic in urban fill projects:

\footnotetext{
${ }^{14}$ Vileisis, 5 .

${ }^{15}$ Ibid, 6.
} 
Developers have often put forward strong arguments [of public benefit] in support of reclamation schemes probably inspired more by profit motive than a genuine concern for the public good. ${ }^{16}$

While it is undoubtedly true that profit motives for city developments are often buried under rhetoric about community amenities, people have not always seen a strong barrier between private and public good. Developers, landowners, and realtors involved with projects in the Guild's Lake area likely believed many of their own arguments for public benefits. Two Portland historians Carl Abbott and E. Kimbark MacColl touch on this struggle between private and public goals and how they relate to Portland and Guild's Lake. In The Growth of a City, MacColl discusses many deals, real estate schemes, and political conflicts of interest that were common in the city and development projects at Guild's Lake. MacColl concludes that throughout much of the city's history, Portland's elite ultimately acted in ways to benefit their own self interests. Somewhat in contrast, Abbott's Portland, takes a less cynical view of the growth of "conscious" planning in Portland, focusing mostly on the latter half of the twentieth century. Nonetheless, Abbott agrees with MacColl that early in the city's history, power brokers made decisions about developments largely based on self-interest. Abbott also points out that mixing self-interest with public projects was common, and that the participants may not have perceived much of a difference:

In the American city of the nineteenth century, most planning decisions were made by private businessmen and investors who alternated between pursuit of the

\footnotetext{
${ }^{16}$ Hudson, 64.
} 
main chance and work toward the rough idea of the common good. ${ }^{17}$

Popular ideas about city growth and planning influenced Guild's Lake landowners and developers, and fueled beliefs that filling in the marsh would bring both personal gain and public benefits. In the early twentieth century urban planning became vogue and city business leaders, architects, and elected officials looked for ways to cohesively shape urban landscapes. Over time, a growing class of civic planners worked with city leaders to determine what cultural needs should be met by an organized physical city. Nationally, planning trends moved from idealized visions of beautiful and grand urban spaces to increase a status and inspire morality to more rationalized plans that plotted city functions to improve business efficiency. In, Planning the Capitalist City, Richard Foglesong points out that planners catered to the needs of elite segments of urban populations.

(City Practical) sought to create a more economical and efficient system of land use and transportation - more economical and efficient, that is, in terms of the needs of the emerging business system. ${ }^{18}$

Portland planning efforts followed national trends. Between 1903 and 1932, city business and elected leaders hired a series of plamners to produce reports on parks, city growth, housing, transportation, and waterfont development. During that time, efforts led by private citizens gave way to city-directed, semi-professionalized planning. At

Guild's Lake, private citizens initiated efforts to fill in the marsh with little

\footnotetext{
${ }^{17}$ E. Kimbark MacColl, The Growth of a City: Power and Politics in Portland, Oregon, 1915-1950. Portland: Georgian Press, 1979; Carl Abbott, Portland: Planning, Politics, and Growth in a TwentiethCentury City. Lincoln and London: University of Nebraska Press, 1983, 4-48.

${ }^{18}$ Richard Foglesong, Planing the Capitalist City: The Colonial Era to the 1920: Princeton; Princeton University Press, 1986, 199.
} 
interference from city officials. Between 1905 and 1915, landowners and developers decided privately to sluice nearby hillsides into Guild's Lake. Some public officials tried to influence events, but they only had limited power over privately-owned landscapes. As the influence of urban planning grew, citizen and elected leaders tried to gain some control over private land through zoning laws and active planning. The change was apparent in the second phase of development at Guild's Lake, between 1918 and 1925, when engineers filled Guild's Lake with silt dredged from the Willamette River. Although landowners and businessmen were the dominant force shaping the landscape, the process included public planning and debates about public ownership and benefits.

Guild's Lake offers a case study for examining some of the complex relationships between humans and nature in landscape formation. Nature influenced people's choices about how to change and utilize the area. People eventually prevailed and filled the marsh, leaving behind an area nearly devoid of its once abundant natural plants and aquatic life forms. Nonetheless, nature directed and hindered human action. 


\section{Chapter One}

\section{Perceptions of Nature: Negative Views of Wetlands Affect Land Use}

During the last 100 years, Portlanders have largely obliterated the natural conditions of Guild's Lake. Where there was once water, reeds, birds, small mammals, and fish, now there is a landscape nearly devoid of plant and animal life. Humans have altered Guild's Lake to suit their values and priorities. They did not value the natural landscape. Instead they saw in it their own ideas about city growth and priorities of financial profit.

Looking at Guild's Lake today, one can see several miles of concrete, railroad tracks and industrial buildings. Only the occasional puddle remains of the once extensive wetlands, including Kittredge and Doane Lakes, which extended about three miles northwest from Guild's Lake's eastern edge, just west of current-day NW Nicolai Street. Balch Creek meandered out of Balch Canyon into Guild's Lake until workers diverted it into an underground sewer pipe in the early 1920s. In the 1920 s, builders of the Northern Pacific Railroad likely cut off the natural outlet from the marsh to river by extending tracks from downtown to a bridge crossing the Willamette River west of Guild's Lake. The lake then drained into the river through a fourteenfoot wide conduit under the railroad berm. ${ }^{1}$ Several remnants of Doane Lake still existed until the 1990s, but the Environmental Protection Agency declared it a superfund site, dredged and then filled half of what remained. A lead-acid battery

\footnotetext{
${ }^{1}$ Carl Abbott, The Great Extravaganza: Portland and the Lewis and Clark Exposition. Portland: Oregon Historical Society, 1981, 20.
} 
recycling plant dumped waste into Doane Lake and surrounding landscape for more than thirty years. ${ }^{2}$ Pollution in the Guild's Lake Industrial Sanctuary is often not visible to the naked eye, but an extensive list of state Department of Environmental Quality cleanup sites in the area testifies to its existence. Pollutants in the ground and underground water include chlorinated solvents, chemicals associated with oil and petroleum, lead, arsenic, benzene, cadmium, PCBs, and many other hazardous materials. $^{3}$

Because of the radical alteration of the landscape, it is hard to know what the natural conditions of Guild's Lake were prior to Euro-American settlement and use. Guild's Lake and its adjacent wetlands were part of a larger system of marshy sloughs and creeks that were prevalent in the lower Willamette River. These areas provided a dynamic habitat for animals and plants that adapted to seasonal flooding and droughts. The flood plains were nurseries for some species of fish, and small mammals such as muskrat and beaver. Abundant waterfowl found food in the wetlands and nested in the reeds and grasses. In addition, Guild's Lake provided habitat for amphibians, reptiles, and invertebrates. ${ }^{4}$ Plant life would have been similar to the native species that still exist in Oaks Bottom, one of the few remaining riverside wetlands in Portland.

\footnotetext{
${ }^{2}$ Environmental Protection Agency, "EPA Proposes No Further Action for Gould Groundwater," Portland, Oregon, August 2002, http://yosemite.epa.gov/R10/CLEANUP.NSF/d67b5aa82151d9ae88256da6005fb54e/90a98d27ff0206af 8825651a00598ed2! OpenDocument, (September 2004).

${ }^{3}$ Portland Bureau of Environmental Services, "Willamette Watershed Characterization Report: Balch Subwatershed, and Kittredge Subwatershed," http://www.portlandonline.com/bes/index.cfm?c=31819, (September 2004).

${ }^{4}$ David P. Anderson, Field Guild to Oaks Bottom. Portland: Audubon Society of Portland, 1979, 5-12; Portland Bureau of Environmental Services, "Willamette Watershed Characterization Report: Balch Subwatershed, Wildlife Communities, 2004, http://www.portlandonline.com/bes/index.cfm?c=31819, (September 2004).
} 
Oregon Ash, Black Cottonwood, and Pacific Willow trees surrounded Guild's Lake in a landscape that included an open prairie with native grasses and shrubs, such as ninebark, and probably included Wapato and Camas -- water-loving indigenous roots that were dietary staples for Native Americans. ${ }^{5}$

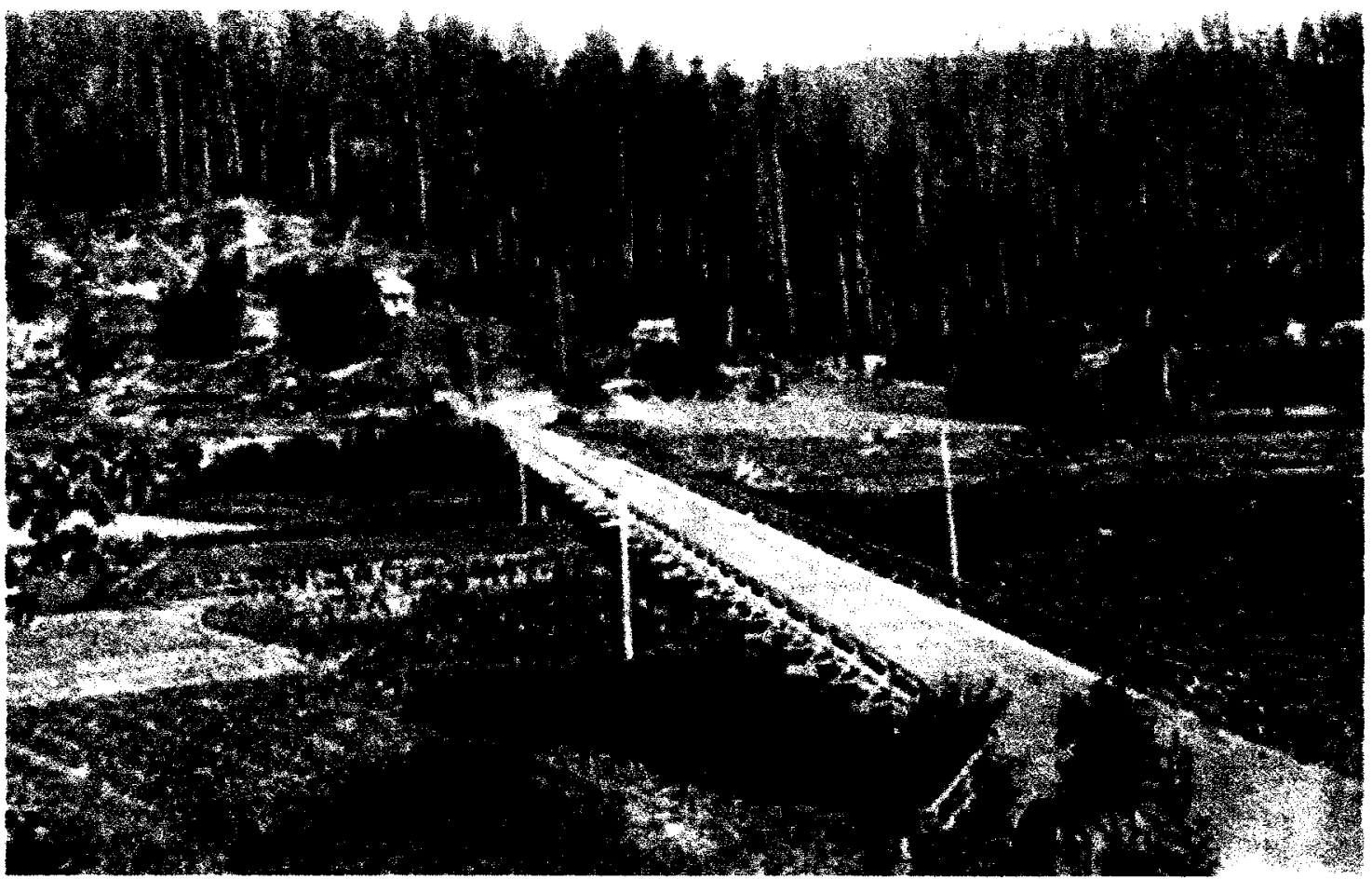

FIGURE 1: St. Helens Road in 1891. Oregon Historical Society CN 35877.

While Euro-Americans settled near present-day Portland as early as $\mathbf{1 8 2 5}$, there is no record of Anglo settlement at Guild's Lake until the late 1840s. Peter and Elizabeth Guild claimed 598 acres there in 1847 with the intention of raising cattle. ${ }^{6}$ Other settlers followed, and in subsequent years homesteaders or renters operated

\footnotetext{
${ }^{5}$ Anderson, 5-12; Portland Bureau of Environmental Services, "Willamette Watershed Characterization Report: Balch Subwatershed, Plant Communities," 2004, http://www.portlandonline.com/bes/index $\mathrm{cfm}$ ?c=31819, (September 2004).

${ }^{6}$ Eugene E. Snyder, We Claimed This Land: Portland's Pioneer Settlers. Portand: Binford \& Mat Publishing, 1989, pg. iix.
} 
dairy farms in the area. An 1891 photograph shows St. Helens Road on a trestle above gardens, revealing that residents also grew vegetables on the edges of the marsh, where rich soil was exposed by low summertime water. ${ }^{7}$ In the 1880 s, forty to fifty Chinese immigrants lived in the Guild's Lake area, where they operated truck gardens and hog farms. ${ }^{8}$ Renters and land owners lived with the lake's natural seasonal fluctuations that occasionally flooded buildings.

No one made significant efforts to tame natural flood and drought cycles in the area until the early twentieth century, after members of the executive committee of the Lewis and Clark Centennial and American Pacific Exposition and Oriental Fair chose Guild's Lake as the fair site in $1902 .{ }^{9}$ A few board members owned property near Guild's Lake and were undoubtedly motivated by the knowledge that their property could appreciate because of the fair, presenting one of many conflicts of interest that affected land-use decisions in the area. ${ }^{10}$ In 1904 and 1905, fair planners transformed the lake, a roughly sixty-acre peninsula and about 100-acres on the southwest shore into a fantastically formal landscape for the Lewis and Clark Exposition. ${ }^{11}$ The company hired famous landscape architect John Olmsted to create a fairgrounds design, which was adapted by local engineers Oskar Huber and William Maxwell. To prepare the grounds, contractors flattened slopes and deepened Guild's Lake damming

\footnotetext{
${ }^{7}$ John Olmsted, "Report of the Lewis and Clark Exposition," Reel 91, Papers of the Olmsted Associates, Library of Congress.

${ }^{8}$ Approximately thirty "white men" burglarized and threatened Chinese residents in their homes.

"Another KuKlux Raid," Oregonian, 13 March 1886.

9 "Willamette Heights for the Big Fair," Oregon Journal, 6 September 1902, 1.

${ }^{10}$ Abbott, The Great Extravaganza, 20

11 The acreage of land would have fluctuated with the seasonal rise and fall of the lake. Olmsted, "Report for the Lewis and Clark Exposition;" John Olmsted, notes, 9 April 1903, Lewis and Clark Exposition, Papers of the Olmsted Associates microfilm reel 91, Library of Congress.
} 
its outlet to the river. During the fair, they filled the lake with Willamette River water - pumping in twenty million gallons daily, most likely to counteract natural seepage back into the underground water table. Planners situated buildings on higher elevations and chose a marshy lowland on the site's western edge (probably the location of the trestle on St. Helens Road) for terraced, experimental gardens. Olmsted noted that the area's natural hydrology could be accommodated:

About 50 acres of land is liable to be overflowed by freshets in the river, but can be used for ornamental and agricultural purposes after the June flood is over. ${ }^{12}$

Many Portlanders considered the exposition a success and credited it for the city's subsequent economic and population booms. A euphoria about the fair and its grounds helped fuel a brief effort to transform the area into a city park. Despite those positive feelings about the fair, however, negative cultural attitudes about wetlands played an important role in land use choices at Guild's Lake.

Euro-Americans have long disparaged wetlands. In Puritan New England, seventeenth century colonists believed that wild, swampy areas harbored both spiritual evils and hostile Native Americans. Historian Ann Vileisis asserts that colonists were afraid of what seemed to them an "incomprehensible, chaotic landscape." By the midnineteenth century, views of wetlands had become more utilitarian: people saw marshes, swamps, and tidelands as barriers to progress. In an effort to transform wetlands into more usable parcels of land, Congress passed the 1850 Swamplands Act,

\footnotetext{
${ }^{12}$ Abbott, The Great Extravaganza, 21; Olmsted, "Report for the Lewis and Clark Exposition;" Olmsted, notes, 9 April 1903, Lewis and Clark Exposition.
} 
which transferred federally-owned wetlands to states for draining and development. As suitable technologies developed in the late nineteenth century, Americans engaged in many thousands of ditch digging, levee building, diking, and dredging projects to drain land, primarily for agricultural purposes. ${ }^{13}$

In cities, where developers and city planners filled wetlands to create more buildable space, a real and perceived connection between wetlands and disease was exasperated by the unsanitary disposal of human waste and garbage. Wetlands are linked to malaria by anopheles mosquitoes that lay their eggs in stagnant waters and are also responsible for spreading the parasitic disease. Colonists brought malaria to the United States, and immigrants carried the disease westward. Before the $1880 \mathrm{~s}$, when researchers discovered that microorganisms caused many diseases, doctors believed that unhealthy swamp air actually caused malaria. In the Willamette Valley and lower Columbia River region, malaria likely killed more than ten thousand Chinookan and Kalapuyan people between 1830 and 1841. While malaria thrived in new Euro-American settlements, it died out in northern areas and by the twentieth century was largely relegated to the South. ${ }^{14}$

Often human alterations to an ecosystem resulted in unhealthy conditions. In urban areas, abuses of wetlands and waterways led to diseases such as dysentery, typhoid fever, and cholera. In mid-nineteenth century Boston, a road and railroad

\footnotetext{
${ }^{13}$ Vileisis, 11-114.

${ }^{14}$ Margaret Humphreys, Malaria: Poverty, Race, and Public Health in the United States. Baltimore and London: The Johns Hopkins University Press, 2001, 1-46; Robert Boyd, The Coming Spirit of Pestilence: Introduced Infectious Disease and Population Decline among Northwest Coast Indians, 1774-1874. Seattle and London: University of Washington Press, 1999, 84.
} 
trestle cut off the city's Back Bay from its natural tides. As a result, according to historian Lawrence W. Kennedy, "the water no longer flowed in and out with the tide but settled in stagnant pools; refuse and waste soon created a stinking bog." ${ }^{15}$ In many American cities, the introduction of indoor plumbing in the mid-nineteenth century and the later widespread use of water closets caused a health crisis. Sewage overflowed inadequate cesspools and polluted groundwater, which seeped into wells. People then piped their wastes directly to nearby streams, rivers, lakes, and oceans. ${ }^{16}$ Nationwide, polluted water supplies caused a typhoid fever epidemic. In 1905 Portland health officials linked an outbreak of typhoid fever to the natural spring in Hawthorne Park, located on a rented twelve-block parcel of land north of SE Hawthorne Boulevard, between SE $9^{\text {th }}$ and SE $12^{\text {th }}$ Avenues. Sewage from nearby homes polluted the spring water, and, as a result, the city stopped renting the land, which was later filled and developed. ${ }^{17}$ While Portlanders apparently valued Hawthorne Park for its beautiful "groves of large fir trees," and its large spring, environmental abuse reflected the low regard city residents held of wetlands. ${ }^{18}$

Put into a broad perspective, the destruction of Guild's Lake and other Portland wetlands was not unusual or unique. As historian Brian Hudson points out, people have been filling in waterways and wetlands for thousands of years.

\footnotetext{
${ }^{15}$ Lawrence W. Kennedy, Planning the City upon a Hill: Boston since 1630. Amherst: The University of Massachusetts Press, 1992: 60-63.

${ }^{16}$ Tarr, 111-149.

${ }^{17}$ Portland Parks Department, "History of Portland Parks and Recreation," updated 23 February 2005, http://www.portlandparks.org/History/History 1852 1920.htm, (28 February 2005).

${ }_{18}$ John Olmsted, Report of the Park Board, 57. Olmsted Associates, Parks Department, City of Portland Archives.
} 
Human settlements are normally established beside some kind of water body and, almost inevitably, their development involves some advance of the waterfront, often extending the built-up area over the former shore, nearby wetlands, adjacent shallows and even into deeper water further out. ${ }^{19}$

Early peoples have first created dry land by depositing shells and bones into mounds or middens - on shorelines and in waterways. Five thousand years ago, Sumerians in Mesopotamia built towns over river wetlands and floodplains, using dikes and canals to drain water, and piling refuse to elevate land. Later on, Venetians transformed lagoon islands into an elaborate and powerful city by using canal dredge spoils as fill and by burying "thousands of timber piles into the oozy ground, often so close together that their sawn-off tops made a practically continuous solid surface. 20

In the nineteenth and twentieth centuries, city builders increasingly filled lowlying marshlands, river sloughs, and shallow bays to develop maritime ports and industrial areas. Engineers used technological advancements, including railroads, hydraulic cannons, and dredging pumps, to move soil from hillsides and river bottoms to wetlands, which people often considered useless and even dangerous. ${ }^{21}$ The idea that wetlands were wasted land resonated in Portland, where both geographic constraints and the general abuse of watery areas contributed to the eventual destruction of numerous sloughs, marshes, and creeks.

In the early twentieth century, Portland grew rapidly and found itself abutting formidable topography of steep west hills and numerous swampy lowlands. As real

\footnotetext{
${ }^{19}$ Hudson, 1.

${ }^{20}$ Hudson, 18-23.

${ }^{21}$ Ibid., 29-30.
} 
estate became more valuable, developers decided potential profits outweighed the costs of altering Portland's natural landscape. Landscape architect John Olmsted described development restrictions posed by the city's West Hills and wetlands in 1903:

The smaller but older portion of the city is west of the river and occupies gently rolling ground, which rises with moderate rapidity to the base of high, rugged and very irregular hills. This base of the hills forms almost a straight line and runs nearly northwest from the mouth of Marquam Gulch Canyon to the mouth of Balch Creek Canyon, and continues in the same general direction for some miles further down the river. Up the river for some distance beyond Marquam Gulch, there is a narrow margin of moderately flat land between the hills and the river; which, however, is not large enough to provide for any considerable increase of population. Down the river from Balch Creek much of the space between the base of the hills and the river is occupied by Guild Lake and other lakes and sloughs and almost all of it is subject to being flooded by the river, so that there is little opportunity for the city to expand in this direction. $^{22}$

Development had been checked by the very landscape that made the area a good location to establish a city. What began as a small clearing near the junction of two rivers, providing navigable waters to the sea, grew and soon filled all of the flat, dry land west of the river.

It can be argued that Portland was founded as a speculative enterprise. EuroAmerican immigrants made the first Oregon provisional government land claim in the future city in 1844, and in the next year owners Asa Lovejoy and Francis Pettygrove

\footnotetext{
${ }^{22}$ Olmsted, Report for the Park Board.
} 
began selling town lots in their 640 -acre claim..$^{23}$ From the 1850 s, speculation was also a factor at Guild's Lake, where marshy conditions limited human land use and, at least temporarily, delayed alteration. Several late nineteenth century land disputes contested the ownership of Guild's Lake property, and were likely fueled by prospective future land values. $^{24}$

In the $1880 \mathrm{~s}$, the City of Portland was bound to less than eight square miles on the west side of the Willamette River and its growing population was somewhat confined. Streetcars soon made it possible for residential neighborhoods to locate farther away from the town center, and even to cross the river into inner East Portland, which became a part of the city in 1891 . While middle-class Portlanders moved east, many of Portland's elite looked west. Developers built view homes in the "Portland Heights" neighborhood in the southwest hills, and by the 1890s, the Scottish American Investment Company was selling lots of its "Willamette Heights" development on the lower slopes above Guild's Lake.

While the city expanded to the east side of the river where flat land was more abundant, the urban core remained on the west side, and growth pressures aided the destruction of wetlands there. Property owners encroached on the Willamette River's naturally marshy edges by building piers, which they later buried under fill and

\footnotetext{
${ }^{23}$ Jewell Lansing, Portland: People, Politics, and Power, 1851-2001. Corvallis: Oregon State University Press, 2003, 6; William Toll, "Commerce, Climate \& Community: a History of Portland \& its People," Oregon History Project, Oregon Historical Society, http://www.ohs.org/education/oregonhistory/narratives/index, (27 January 2005).

${ }^{24}$ Perdue, Wendy Collins, "Sin, Scandal, and Substative Due Process: Personal Jurisdiction and Pennoyer Reconsidered" 62 Wash. L. Rev. 479, Washington Law Review, July 1987. http://carver.law.cuny.edu/materials/civpro matrials/perdue.html, (O Copyright 1987 Washington Law Review Association.
} 
revetments. Portlanders also buried six west side creeks that drained the hills. While workers piped some of the creeks to the Willamette, nearby businesses and residents simply buried others under refuse and dirt. Sawmill operators dumped sawdust into the lake-like marshy outlet of Enois Creek, which meandered out of Marquam Canyon into a natural gulch connected to the Willamette River. Neighbors also used the gulch as a garbage dump, and it was eventually filled entirely, likely with sand from the nearby hillsides and silt from river dredging. ${ }^{25}$

Twenty years before developers filled Guild's Lake, Portlanders buried a smaller west side lake. Couch Lake was once located between the present-day Steel and Fremont Bridges, and it extended about ten blocks inland from river. The nowburied Tanner and Johnson creeks fed the marsh, which fluctuated with the elevations of the Willamette River. In the late 1880s, people began to dump bricks, slag, concrete, and wood into Couch Lake. In the 1890s, the Northern Pacific Terminal Company filled most of the marsh for construction of their passenger terminal. Railroad executives agreed with many Portlanders that Couch Lake had become a nuisance, likely because of the earlier filling. They described it as "a pestilential hole full of water covered with a green scum." Terminal company photographs show that the company built the terminal before completely filling Couch Lake, perhaps due to

\footnotetext{
${ }^{25}$ Stephen Dow Beckham, "Historical Assessment: Westside CSO Tunnel Shafts, Pump Station, and Pipeline Project." Memo, Stephen Dow Beckham to ParsonsBrinkerhoff, 15 February 2001; Foundation Engineering Inc., "Preliminary Geologic Assessment: Westside CSO Tunnel Project." Portland, 17 July 2000.
} 
high cost of fill, which 1892 number crunchers estimated to be $\$ 90,000$ for 25,000 cubic yards. ${ }^{26}$

Until the early twentieth century, Portland's east side also had numerous wetlands, including Stephens Slough, just north of present-day Powell Boulevard, and Hawthorne Springs, which joined the Willamette River through a meandering slough. ${ }^{27}$ In North Portland, former wetlands areas include Mocks Bottom, which the Port of Portland filled in the 1950s, and Ramsey Lake, which the Port of Portland filled in the 1960s, and later partially recreated nearby to meet requirements for wetland mitigation.

Like at other city wetlands, Portlanders dumped garbage into Guild's Lake before it was filled. From the late nineteenth century, operators ran a garbage incinerator and landfill on the lake's eastern shore. The City of Portland took over operations sometime in the first years of the twentieth century, and despite poor public health conditions, continued to dump garbage and ashes there until 1948. The incinerator burned inefficiently and much of the garbage was simply dumped. In 1908 and 1909 visitors noticed decayed and putrid vegetables and meats, rats, and a dead

\footnotetext{
${ }^{26}$ W. M. Mellon, General Manager Northern Pacific Railroad Company, to J. B. Williams, Vice President, Northern Pacific Railroad Company, 14 November 1892, Northern Pacific Terminal Company, Branch Lines, Northern Pacific Railway Company Records, Minnesota Historical Society; E. Lyons, Manager NPTC, to James. B. Williams, Chairman Executive Committee NPTC, 11 October 1892, NPTC, Branch Lines, NPRC Records, MHS; Photos of the NPTC Passenger Terminal Construction, NPTC, Branch Lines, NPRC Records, MHS; Geologists and engineers working on the City of Portland Combined Sewer Overflow Project used bore-hole information to study the content of fills in the city. Foundation Engineering Inc., "Preliminary Geologic Assessment: Westside CSO Tunnel Project." Portland, Oregon, 17 July 2000.

${ }^{27}$ Stephen Dow Beckham, Heritage Research Associates, "Eastside of Willamette River, Portland Oregon: Historical Investigations for the Eastside Consolidated Sewer Overflow (CSO) Project." Portland: City of Portland, Bureau of Environmental Services, September 2003.
} 
horse along with other dead animals in the lake. Health officials linked the pollution to cases of the bubonic plague.

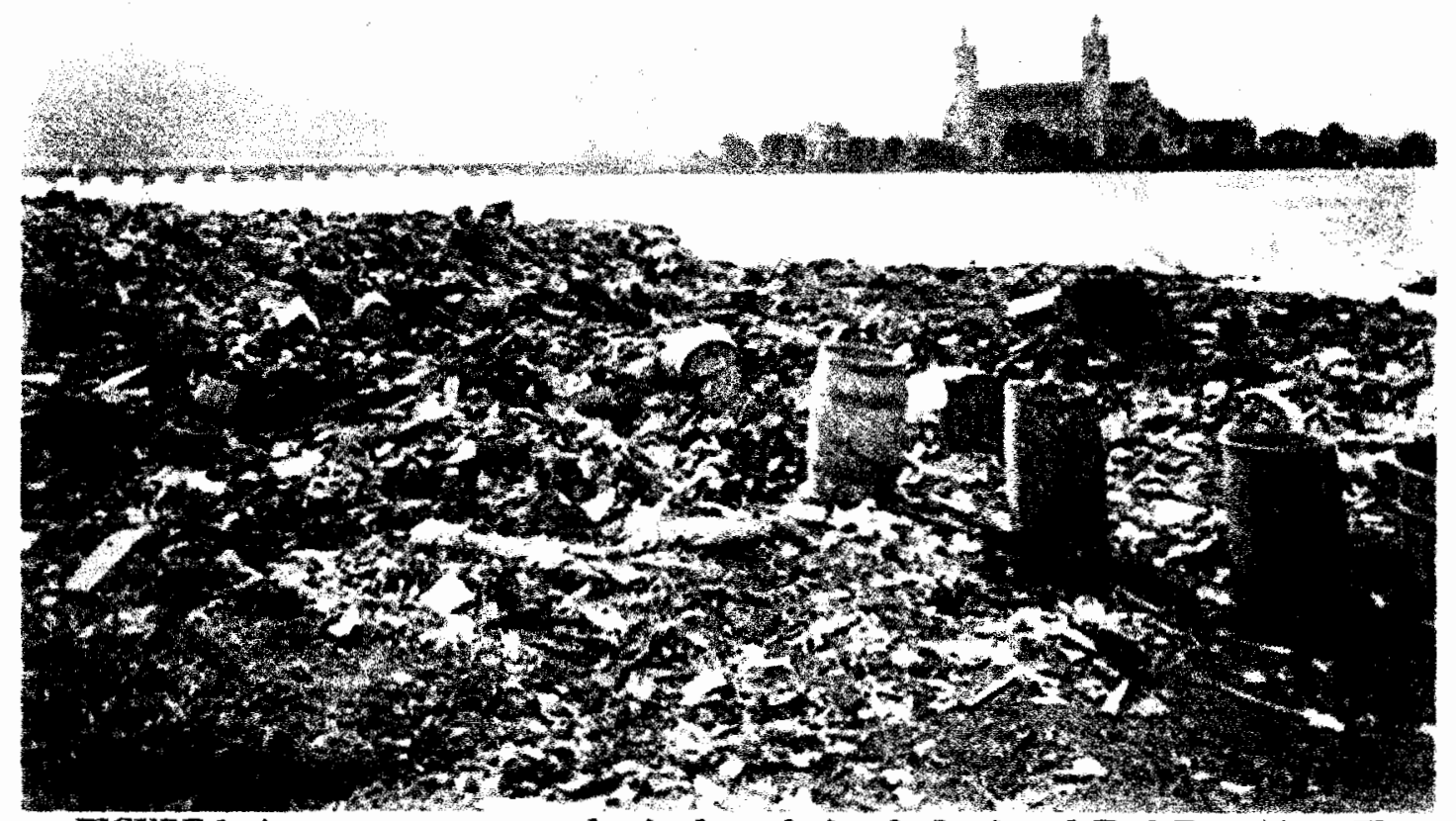

FIGURE 2: A person numumges ot the city dump during the Lewis and Clark Exposition. The government building is in the background. Oregon Historical Sociefy CN009032.

In 1911, the crematory superintendent told the board of health that the conditions at the crematory were "deplorable:"

Owing to heavy smoke, we breathe and see with difficulty on the top floor. ... this smoke is very obnoxious, and as the prevailing winds are from the north, thin blue smoke covers the vacant field nearby and people to the south of the Crematory are complaining of vile odors. Two scavengers on Saturday were compelled to drive their teams out of the Crematory, when half unloaded, because of the smoke, 
and when outside the horses stood in the driveway panting and trembling. ${ }^{28}$

Despite the problems, some considered a landfill to be a good use of Guild's Lake. A 1913 audit of municipal operations recommended the city expand the landfill into more of the marshland for profit:

The city has already very greatly enhanced the value of certain surrounding property by filling low ground and has received nothing in return. In fact, in one case they have been required to pay the property owner for the privilege of adding greatly to the value of his property. This situation should not be permitted to continue. If necessary, the city should purchase additional grounds, preferably under water, and make use of the fill in increasing the value of its own property. It is interesting to note that immediately north and east of the incinerator, a private contractor is spending a great deal of money in filling low ground in order to make factory sites out of the marsh around Guild's Lake. Foresight on the part of the city would return any expenditure for land many times in the next 20 years. ${ }^{29}$

Neglectful and abusive actions toward the wetland degraded the landscape further contributing to negative perceptions of the area. Guild's Lake's proximity to Portland's downtown, however, was perhaps the most powerful factor on people's actions. They considered it opportune land for city growth and industrial use. Even before Guild's Lake became a partially filled and garbage strewn mess, developers dreamed up ideas of how to remake the landscape into something that would reflect human wants and desires.

\footnotetext{
${ }^{28}$ H.N. Napier to Co. Chas E. McDonnell, City, 15 June 1909, Joseph Simon Papers, General Correspondence, City of Portland Archives; S.H. Gruber to Board of Trustees of the Chamber of Commerce, City, 14 December 1908, Council Documents - Garbage Crematory, COP Archives. ${ }^{29}$ Bureau of Municipal Research New York City, "Organization and Business Methods of The City Government of Portland, Oregon," 1913. This document can be found online at www.nalga.org/confer/toronto/materials/Portland1913.pdf.
} 


\section{Chapter Two}

\section{Blasting the Hillsides: Developers Use Hydraulic Power to Create Space}

Contemporary cultural values were a factor in how humans altered the

landscape at and near Guild's Lake. During and after the Lewis and Clark Exposition, landowners on the hillside above and at the fair site were anxious to implement plans for the area that reflected popular ideas for city growth and increased land values. The existing landscape, united physically by water and conceptually by the fair, also had influence. Landowners and planners explored approaches that were cooperative, in varying degrees, and kept in mind the city's future growth and effects on an extended geographic area. Two plans that dominated public discussion during and after the fair contrasted starkly. The first, although brief, plan would have added the fair site and lake to the city parks system. When that idea floundered, developers moved in with a plan to fill the area with hillside sluicing and create both a high-end neighborhood above Guild's Lake and land on the lakebed for factories and rail facilities. These dichotomous plans to create either a park or a landfill had commonalities: both were large-scale ideas that required cooperation, and both manifested overt and hidden tensions between private and public good that came to typify development in the area.

While contemporary views of wetlands were generally negative, the beauty of the Lewis and Clark Exposition site convinced some that it should be included in the city's burgeoning park system. Nationwide, the 'City Beautiful' movement inspired turn-of-the-century urban elites "to make cities impressive, inspiring, and imperial." Portland leaders created the Board of Park Commissioners in 1900, and over the next

\footnotetext{
${ }^{1}$ Abbott, Portland, 58-60.
} 
decade park commissioners worked to expand the city's park system from a small collection of donated parks and zoo animals. They hoped that a more comprehensive park system would both improve the citizenry and help propel Portland nationally as a modern city. ${ }^{2}$ The Oregon Journal editorialized that parks would also attract new residents:

It pays for a modern city to be well supplied with parks. Thus it gets an enviable reputation. Thus it attracts and holds people - and that, as we said before, is what builds up a city. ${ }^{3}$

In 1903, the parks board hired landscape architect John Olmsted, son of Central Park designer Frederick Law Olmsted, to plan a city parks system. He reported to the parks board that, "no city can be considered properly equipped without an adequate park system:"
All agree that parks not only add to the beauty of a city and to the pleasure of living in it, but are exceedingly important factors in developing the healthfulness, morality, intelligence, and business prosperity of its residents. Indeed it is not too much to say that a liberal provision of parks in a city is one of the surest manifestations of the intelligence, degree of civilization and progressiveness in its citizens. ${ }^{4}$

Olmsted, who also came to Portland as a consultant to the Lewis and Clark Exposition Company, recommended nearly twenty new parks on the city's west and east sides, linked by scenic boulevards and supplemented with many public squares and playgrounds. In his seventy-five-page report, Olmsted suggested that the Guild's

\footnotetext{
${ }^{2}$ Portland Parks and Recreation. "Historic Timeline," http://www.portlandparks.orl g/History/History 1852-1900.htm, and http://www.portlandparks, org/History/History 1901-1920.htm (24 January 2005),

3 "The Question of More Parks," Oregon Journal, 29 January 1905.

${ }^{4}$ John Olmsted, Report of the Park Board.
} 
Lake site, which had already been selected as the fairgrounds, would make a good location for a park. ${ }^{5}$ In his notes for his work for the exposition company, Olmsted commented that the Guild's Lake fairgrounds had "remarkably fine views" including:

The beautiful green neck of land with its park like trees, and over the Willamette River and its valley below the city to the ranges of hills beyond this river and beyond the Columbia River; and from certain points Mt. St. Helens and other snow clad peaks are visible. ${ }^{6}$

However, Olmsted conceded that the area's marshy nature and location near downtown likely meant that it would be "diked and drained and filled ... for manufacturing and other commercial purposes." Even so, he suggested that the parks board might consider buying the Guild's Lake land at a later date if it became more affordable. $^{7}$

Perhaps the impetus to save Guild's Lake and fairgrounds as a park was greatest in the fall and winter of 1904-1905, just before the start of the Lewis and Clark Exposition. The Oregonian argued purchasing the land "would be money well spent" because the city could benefit from new buildings, street-car lines, landscaping, fair buildings, and sewer and water systems:

During the entire course of the Fair nothing but praise has been heard for the site chosen. The gradual slope of the grounds leading down to Guild's Lake, the fir-clad hills behind, and a beautiful panorama of river and mountains spreading out before it make the place an ideal park site. ${ }^{8}$

\footnotetext{
${ }^{5}$ Olmsted, Report of the Park Board.

"Olmsted, "Report for the Lewis and Clark Exposition."

${ }^{7}$ Olmsted, Report of the Park Board.

8 "Fair for a Park," Oregonian, 21 January 1905, 10.
} 
The newspaper reported that the idea had "met with universal approval by the property-owners and taxpayers of Portland," and that the city "would not have to spend any money in improvements for the next 25 or 30 years." The city branch of the Council of Jewish women wrote a letter to the park commissioners asserting that they "heartily endorsed" making the fairgrounds into a park. ${ }^{9}$

The Portland Taxpayer's League appointed a committee of three wealthy businessmen to study the idea, including two with clear financial interests in the area. Attorney and exposition company board member Robert Livingstone had been an agent for the Scottish-American Investment Company, an Edinburgh-based mortgage company that owned a large swath of the hillside above Guild's Lake since the late nineteenth century. The company also owned lowland property just west of the fair site, north of NW Thurman Street. Livingstone was instrumental in bringing the fair to Guild's Lake, and in 1903 Livingstone's wife, Bessie, bought eight lots of "Willamette Heights" land from the Scottish-American Co. for $\$ 2,500 .{ }^{10}$ Another member of the Taxpayer's League committee was Paul Wessinger, the son-in-law of beer-maker Henry Weinhardt and a member of the Lewis and Clark Exposition

\footnotetext{
9 "Fair for a Park," Oregonian, 21 January 1905, 10; Council of Jewish Women to City Park Board of Commissioners, 8 October 1905, City Council Documents -- Parks, COP Archives.

${ }^{10}$ Abbott, Portland, 41; The lots that Bessie Livingstone bought were in the Willamette Heights Addition development. "Scottish-American Inv. Co. To Livingstone," 31 July 1903, Deed Book 218, 344, Multnomah County Records Book; E. Kimbark MacColl, The Shaping of a City: Business and Politics in Portland, Oregon 1885-1915. Portland: The Georgian Press Company, 1976, 53-54; Abbott, The Great Extravaganza, 22.
} 
Executive Committee. Newspaper articles from the time indicate that Wessinger owned land adjacent to the proposed park. ${ }^{11}$

Livingstone and Wessinger may have supported turning a portion of the fairgrounds into a park because it would have raised the value of their own real estate holdings. In a contemporary book about the "science" of real estate, Richard Hurd advised that proximity to parks attracted wealthy residents. ${ }^{12}$ Planning historian Richard E. Foglesong confirms that the potential for increased values motivated landowners to advocate for nearby parks in the late nineteenth and early twentieth centuries:
Although comparatively few received the benefits of enhanced land values, the success of a number of park proposals turned on lobbying efforts of this small, but intense, monopoly. ${ }^{13}$

It should be noted, however, that some Portland realtors and city officials opposed bonds for more parks, because higher taxes might scare new residents away from the city. In addition, east Portland's middle class leaders exposed class tensions by complaining that the city's wealthier west side already had an abundance of parks. ${ }^{14}$

Taxpayer's League committee members determined that it would cost the city $\$ 325,000$ to purchase forty-two acres from approximately fifteen different landowners. Along with city and exposition representatives, the members promoted the idea of the

\footnotetext{
${ }^{11}$ While Wessinger was not among listed property owners of the proposed park in the Oregonian, the paper did identify him as one of the owners of the fairgrounds. "Fair for a Park," Oregonian, 21 January 1905, 10; “Fair Site Bought for Factories," Oregonian, 25 March 1906.

${ }^{12}$ Richard M. Hurd, Principles of City Land Values. (1903; reprint, New York: Arno Press and the New York Times, 1970), 76.

${ }^{13}$ Foglesong, 114.

14 "People to Vote Upon Park Bonds." Oregon Journal, 1 March 1905, 6; "Too Many Parks, Says Zimmerman," Oregon Journal, 2 March 1905; Abbott, Portland, 47.
} 
Guild's Lake park to the 1905 state legislature. They urged passage of bills that would both allow the city to pass bonds for parks and to condemn land. Portland park commissioners, however, were cognizant that more parks were needed on the east side. Furthermore, their primary concern was raising money for a larger parks system. The parks board only supported a revised bonds bill after legislators removed specific land choices, including the fair site, and gave the commissioners discretion in allotting money. Nonetheless, the legislature denied both bills. The parks board could not sell bonds until 1907 , when voters narrowly approved a $\$ 1$ million dollar plan to expand the park system. Because of legal complications, the board could not spend the tax money until 1909, when "the inflation of Portland's real estate prices had drastically reduced its buying power." ${ }^{\prime 15}$ The momentum to create a large park at Guild's Lake waned. Physical conditions at Guild's Lake may have been a factor. After the fair, the exposition company stopped pumping river water into Guild's Lake, and it reverted to its natural shallow, marshy state, making it much less appealing to citizens. Early in 1906, the Oregonian complained that the lake had receded by ten feet, exposing "ghastly mud flats:"
What makes the sight particularly obnoxious and distressing to those who marveled at the beauty of the lake while the Fair was in progress are the myriads of tin cans and piles of debris which appear on the surface of the mud flats near the Trail and the Bridge of all Nations. ... the low stage of the water aroused more interest among the hundreds of visitors to the Exposition grounds yesterday than did anything else. Many

\footnotetext{
${ }^{15}$ John Olmsted reported to the city parks board that more parks were needed on the east side. Report of the Park Board.; "More Playgrounds for all People," Oregon Journal, 20 March 1905, 8; "Fair for a Park," Oregonian, 21 January 1905, 10; Abbott, Portland, 60.
} 
expressed the opinion that it was a shame that the body of water could not be preserved. ${ }^{16}$

In the end, the City of Portland acquired two acres of land including and surrounding the exposition's Forestry Building. Parks board commissioners and some city residents hoped the city would be able to purchase more land, and to possibly connect the Forestry Building with Macleay Park, one of Portland's earliest and most beloved parks nestled nearby in the Balch Creek ravine. ${ }^{17}$

Portlanders' attention soon turned to Macleay Park and the hills above Guild's Lake, which were threatened by real estate speculation and development. While the Guild's Lake area was not part of Portland until 1915, speculators foresaw its nearness to downtown meant it could become valuable real estate. ${ }^{18}$ Portland's wealthiest residents often profited handsomely by buying land outside of the city's core and waiting for it to increase in value as urban boundaries grew. ${ }^{19}$ As a growing population and increased commerce crowded downtown, developers looked to the west hills. By 1903, when Olmsted visited the city, many residential neighborhoods had already encroached on the slopes. Olmsted toured the city with parks board president Leander Hawkins in his horse-drawn carriage, and they agreed that it would be desirable to save some of the vulnerable hillsides. Olmsted wrote home to his wife that:

\footnotetext{
16 "Is Bare Mud Flat," Oregonian, 12 February 1906, 8.

${ }^{17} \mathrm{~A}$ fire destroyed the Forestry Building in 1964 and the city subsequently sold the land. Carl Abbott, The Great Extravaganza, 73; Portland Rose Festival Association to the Portland Mayor and Board of Park Commissioners, 11 November 1907, Council Documents - Parks, COP Archives.

${ }^{18}$ MacColl, The Shaping of a City, 112.

${ }^{19}$ Robert Johnson, The Radical Middle Class: Populist Democracy and the Question of Capitalism in Progressive Era Portland, Oregon. Princeton and Oxford: Princeton University Press, 2003, 160.
} 
It is too bad the fronts of the hills and ravines could not have been preserved with the woods on them as a natural park and background for the city but, the land boomers have played havoc with them and run values clear above anything reasonable and beyond the power of the city to purchase them or even consider portions of them. It is hoped that some steep slopes can be taken by the city and preserved. ${ }^{20}$

Hillside landowners, however, were eager to cash in on the economic boom that followed the Lewis and Clark Exposition.

Contemporary ideas about land use influenced these elite land developers' visions for Guild's Lake and the nearby hills. They read into the existing landscape their perceptions of appropriate land use. In his 1903 book, Principles of City Land Values, Hurd suggested that low and submerged lands had a natural purpose.

Filled in land is generally used for ware housing, manufacturing, and cheap tenements. ${ }^{21}$

He advised readers that topography provided resistance, but was an obstacle that could be overcome when financially practical:

The influence of topography, all-powerful when cities start, is constantly modified by human labor, hills being cut down, waterfronts extended, and swamps, creeks, and low lands filled in, this, however, not taking place until the new building sites are worth more than the cost of filling and cutting. ${ }^{22}$

In the midst of public discussions about a Guild's Lake Park, an opportunistic newcomer made plans to wash the hillsides into the lake. From the time of his 1904

\footnotetext{
${ }^{20}$ Olmsted to Olmsted, 20 April 1903, reel 35, Olmsted Correspondence, Library of Congress, quoted in Kenneth James Guzowsky, "Portland's Olmsted Vision (1897-1915): A study of the public landscapes designed by Emanuel T. Mische in Portland, Oregon," (master's thesis, University of Oregon: 1990), 42-47.

${ }^{21}$ Hurd, 14-36.

${ }^{22}$ Ibid.
} 
visit to Portland, former Colorado Congressman and miner Lafayette Pence consistently managed to strike a controversial pose. Pence first made headlines in Portland when attending a national mining convention, where he caused an uproar by insinuating that Mormonism made Salt Lake City an inappropriate location for the proposed headquarters of the National Mining Congress. ${ }^{23}$ Early in 1905, Pence returned to Portland and again made news by claiming the water rights of eight metroarea streams, including the Bull Run River, which the City of Portland had already planned to use for drinking water. He used a state law intended for the mining regions of the state to file appropriation rights for the water, which he would reportedly use "for irrigation, domestic, household and municipal purposes and to create electric power and energy for light, transportation and all other purposes, and for hydraulic mining, sluicing, grading and filling purposes." State legislators acted quickly to protect the Bull Run, and Portland parks board president Leander Hawkins, protested that the other local water rights were also publicly owned. Nonetheless, a county judge determined that Pence had acted legally under state law. Hawkins, who was primarily interested in protecting Balch Creek, which runs through Macleay Park, railed against Pence in the Oregonian:

He is a mischief-maker from the ground up, and the purpose of my talk is that measures shall be taken to thwart his plans; to nip them in the bud. ... are we going to have some man come in from outside and grab up all these water rights? ${ }^{24}$

\footnotetext{
23 "Let Words Fly," Oregonian, 26 August 1904, 1.

24 "Taken to Task," Oregonian, 13 April 1905, 8; "Water Rights of City in Danger," Oregon Journal, 14 February 1905, 8; "Lafe Pence Can Not be Stopped," Oregonian, 19 April 1905, 14.
} 
A Pence supporter soon revealed the plans for Balch Creek and uphill streams that reached back some twenty miles. Percy Blyth, of the Scottish American Investment Company that owned much of the hillside above Guild's Lake, reported that he contracted with Pence to:

Grade down the hill two-thirds cheaper than it could be graded down in any other manner. This will give the land to homebuilders, and make the heights the prettiest suburb of Portland.... We simply want to cut down the hill in order that it may be used with advantage, and naturally, we want to do it as cheaply as possible. ${ }^{25}$

Pence planned to divert water from Balch Creek and other streams into reservoirs, through tunnels, ditches, and streams into hoses connected to hydraulic "giants," nozzles that focused a pressurized water stream. ${ }^{26}$ These hoses, aimed at the hillsides and knolls, would wash sediment and gravel into flumes down to Guild's Lake. He told the Oregonian it was a perfect area to apply mining technology:

I have been engaged in placer mining for years and have always found my dump too small, so when I came here five years ago and saw what a dump Guild's Lake and Balch Gulch would make, it made me feel sick that I was not out by some placer claims of mine. Then I saw that the hills could be sluiced down to the lake, making yard room for the railroads, and factory sites and city lots could be sold where now there are steep hills. ... I found that from Balch Creek alone I could sluice down acres and acres. ${ }^{27}$

The Oregon Journal reported that Pence would profit by selling fill material and by receiving a portion of the increased land values both on the hill and on filled-in

\footnotetext{
25 "Tear Down Hill," Oregonian, 16 April 1905, 10.

${ }^{26}$ Eugene B. Wilson, Hydraulic and Placer Mining. 3rd ed. New York and London: John Wiley and Sons, Inc., and Chapman and Hall, Ltd, 1918, 210-211.

27 "Plan Explained by Lafe Pence," Oregonian, 16 May 1905, 10.
} 
lands. ${ }^{28}$ Although Pence's specific contract agreements were not publicized, he was clearly backed by local and outside capital. Pence had support from wealthy hillside landowners who allowed his flumes to cross their land, including as W.F. Burrell, a member of the exclusive Arlington Club, and C. A. Dolph, a prominent attorney and banker with ties to the railroad industry. Pence also acted as the front man for outside real estate investors who bought fairgrounds land. With his son, Lafe V. Pence, he formed the Pence Corporation, and hired as many as eighty men, including A.W. Shearer, "one of the best known hydraulic miners of Southern Oregon."29

Since the $1850 \mathrm{~s}$, miners throughout the West had used increasingly highpowered hydraulic hoses and nozzles to remove hillsides and extract gold. This method required large volumes of water, which was sometime completely removed from streams. Although engineers in Seattle also used hydraulic sluicing to reshape their city, this method was uncommon in urban areas, most likely because it was not practical near densely packed homes and businesses. ${ }^{30}$ The hydraulic technology was attractive to landowners largely because Pence promised it would be much less expensive than previously used methods to alter Portland's landscape. The Oregonian reported that the city had spent up to forty cents a cubic yard to fill gulches, and that the Scottish American Investment Co. spent nearly twenty cents a cubic yard in a failed attempt to removed a knoll from Willamette Heights. Contending that "heavy expense" had prevented other methods of regrading, Pence estimated that he could

\footnotetext{
28 "Streams of Water to Tear Down Hills," Oregon Journal, 20 May 1905, 6.

${ }^{29}$ MacColl, The Shaping of a City, 242; "Streams of Water to Tear Down Hills," Oregon Journal, 20 May 1905, 6.

${ }^{30}$ Matthew William Klingle, "Urban by Nature: An Environmental History of Seattle, 1880-1970."

Ph.D. Diss., University of Washington, 2001, 121-300.
} 
move sediment from the hillside into Balch Gulch, Guild's Lake, and adjacent wetlands for between five and seven cents a cubic yard. ${ }^{31}$

Although lower cost fill material helped convince property owners of undeveloped land to support the landscape alterations, not everyone liked Pence's scheme and tensions arose between people who wanted to protect park land and supporters of increased urban development. Some Portlanders wanted to preserve some "untouched" nature. In addition, many were concerned that Pence's operations would damage a beloved city park. Their fears were warranted as hydraulic operators blocked off entrances to Macleay Park, took water from Balch Creek, and ran flumes across park property. Parks Commissioner Leander Hawkins led efforts against Pence, which stemmed from his desire to protect Macleay Park and the natural beauty of the area. Hawkins was a retired banker and amateur naturalist that Olmsted described as rich, but "modest and simple." In 1905, Olmsted wrote to his wife that Hawkins " is very fond of nature and good to children." Olmsted shared with Hawkins an appreciation of Macleay Park, where the landscape architect was impressed with twenty-five-foot Yew trees and abundant mosses and ferns. ${ }^{32}$ Hawkins and a few of the other park commissioners wanted to protect what they viewed as pristine nature close to the city - a "wild spot in all its original beauty." The Oregonian reported that some commissioners "particularly desire to have the water leaping over the rocks and babbling along for all time, even when the hills are covered with houses." ${ }^{33}$

\footnotetext{
31 "Streams of Water to Tear Down Hills," Oregon Journal, 20 May 1905, 6.

${ }^{32}$ Olmsted to Olmsted, 25 April 1903. Olmsted Correspondence, quoted in Guzowsky, 47.

33 "Stops Lafe Pence," Oregonian, 15 April 1905, 10.
} 
Hawkins became incensed in April 1905 when he discovered that Pence had built a flume to the boundary of Macleay Park, and then slashed a path for it through the park without permission. An admiring Oregonian reporter noted that Pence "has made a bold move in the laying of his flume to the very edge of the park and then asking for right of way, but he says that if he had to let his plans be known sooner, he would have been blocked." ${ }^{34}$ Hawkins asserted that Pence should have been arrested for trespassing.

What makes my blood boil is to see the manifestations of that man Pence's colossal nerve. He schemes to take all the water away from that park, tapping Balch's Creek immediately above the park limits and then goes slashing through the park itself to lay his ditch on public ground. $^{35}$

The Oregonian, which alternately seemed to support and deride Pence, accused Hawkins of "blocking Lafe Pence for sentimental reasons because he hates to see one twig on those hillsides 'touched."' Despite Hawkins' objections, some park commissioners were inclined to give Pence a permit for a 300-yard right-of-way for a flume through the park. ${ }^{36}$

Neighbors and park lovers, alarmed by the giant hydraulic project, protested that the board should deny Pence's application. More than thirty residents founded the Willamette Heights Association and petitioned the mayor and parks board to deny anyone or corporation the right to "divert the waters of Balch Creek."

\footnotetext{
34 "Plan Explained by Lafe Pence," Oregonian, 16 May 1905, 10.

35 "Stops Lafe Pence," Oregonian, 15 April 1905, 10.

36 "Plan Explained by Lafe Pence," Oregonian, 16 May 1905, 10.
} 
This stream forms the most charming feature of Macleay Park and of the canyon below the Park. If these waters shall be diverted, much of the beauty of the Park will be permanently lost.... We earnestly protest against unauthorized invasion of the Park and against occupancy of any part of it except for Park purposes. ${ }^{37}$

One of the neighbors, C.W. Sherman, said living near "a bit of natural canyon" was an incentive when he "spent considerable money" on his NW Thurman Street home. He suggested developers look to "flat regular ground ... leaving the hills and naturally picturesque spots for those who prefer them."38 Park supporter Mrs. A. J. Walters argued that Portland needed to protect its natural beauty.

(Macleay Park) is certainly an ideal spot and the number of quiet family picnic parties to be seen there any warm Sunday show that it is appreciated. And of course its chief beauty is the beautiful little stream and the fact that it is so perfectly unspoiled by man, just a little bit of wild nature set down inside our very gates. Other cities spend vast sums on poor imitations of what is ours already. All we have to do is to protect it and kept it as it is for future generations to enjoy and thank us for. ${ }^{39}$

The John Burroughs Society of Portland complained that the diversion of water from Balch Creek would harm bird and plant life at the park. Members urged the park commissioners to deny the application and they appealed "to every public spirited citizen of Portland, to every lover of nature, and to every person who has some regard

\footnotetext{
${ }^{37}$ Willamette Heights Association to the Mayor and Parks Board, 27 May 1905, Council Documents Parks, COP Archives.

${ }^{38}$ C.W. Sherman to Chairman of the City Park Board, 18 May 1905, Council Documents - Parks, COP Archives.

${ }^{39}$ Mrs. A.J. Walters to Colonel Hawkins, 2 June 1905, Minutes of the Parks Board, COP Archives.
} 
for the esthetic side of life ... to help avert what we regard as a little short of a calamity."

Supporters of Pence's plan used both threats against the city and appeals to presumed public benefits to convince the park commissioners to grant a permit. Blyth railed that:

If Colonel Hawkins persuades the Park Board not to allow Mr. Pence to carry out his plans for tearing down the hill in the vicinity of Macleay Park by means of hydraulic pressure, we will close the park to the public. .. . Macleay Park may be controlled by the Park Board, . .. but in spite of this, the Scottish-American Company absolutely owns and controls the canyon or gulch leading to the park. ${ }^{41}$

Tempering his threats with a message of public benefit, Blyth argued that Pence offered a practical and cost-effective way to improve the area by providing homebuilders with more land "cheaper than we would have if we had to use other means to grade down the hill." ${ }^{, 42}$ Pence himself appealed to public benefits by offering to the board of Lewis and Clark Exposition the free use of Balch Creek water for fire protection or an "ornamental purposes at the Exposition - for instance, a fountain." Pence also claimed that his company might use the water to create a fountain, "which would especially present a very attractive feature to our Summer visitors. . . . it seems to me that this ought to make even Colonel Hawkins happy, for I know that the chief object of his life is to present attractions to Portland visitors, and especially to beautify

\footnotetext{
${ }^{40}$ The John Burroughs Society to the Board of Park Commissioners, 19 May 1905, Council Documents - Parks, COP Archives.

41 "Tear Down Hill," Oregonian, 16 April 1905, 10.

${ }^{42}$ Ibid.
} 
our parks, in which he takes so much interest. ${ }^{, 43}$ Arguing to Portlanders desiring more development, and presumably more jobs, Pence asserted that his alterations would provide the city with much needed room for rail yards, factories, and warehouses.

Your city's already crowded for yard room for its railway system. What more natural or admirable tract could be selected than Guild's lake after it has been filled to above the highwater mark? Then this stretch of eight miles down the river which is now useless would make an ideal factory district or section for wholesale trade while the leveled hills would be perfect for homes. $^{44}$

Many landowners, city politicians, and business leaders also saw the landscape alterations as positive. Pence himself envisioned upscale homes on the hills and factories and railways down below on a covered lakebed. In all of his plans, his appropriated waters played a role - they would sluice the hillside, fill the lake, supply water to homes and factories. Pence went as far as to claim that he would create a "scenic park" on the hills featuring spring-fed reservoirs and a boulevard, served by hydraulic-powered electric rail line that his planned between Portland and Linnton. Parks commissioner J. D. Meyers supported Pence's plan and wanted to grant a permit for the flume, because "the work contemplated was of such manifest benefit to the city and large property holders. ${ }^{, 45}$ Local business leaders also supported the plan, asking park commissioners to issue the permit for the flume through Macleay Park. The Portland Board of Trade recommended approval after finding "the granting of the

\footnotetext{
43 "Taken to Task," Oregonian, 13 April 1905, 8.

44 "Streams of Water to Tear Down Hills," Oregon Journal, 20 May 1905, 6.

${ }^{45}$ Amend Pence Line," Oregonian, 18 May 1906, 16. "Pence's Dreams are Coming True," Oregonian, 11 March 1907,12.
} 
right of way advantageous to the City commercially, and tending to enhance the value of these pleasure grounds to the citizens of Portland." They recommended, however, that Pence should not be allowed to reduce the water level in Balch Creek. Members of the Portland Chamber of Commerce first opposed Pence's flume because of potential harm to Macleay Park, but then reversed their decision after a special meeting in May 1905:

The decision was arrived at that, as the work contemplated by Mr. Pence and his associates seems to be in the line of progress and likely to be of great advantage to many interests, both public and private, it would seem to be desirable to grant his petition ... on the condition that the ... [flume] shall be laid and maintained in a manner approved by your Board, that there would be no destruction of trees, that due care will be taken to preserve the natural condition of the Park, as well as its trees, shrubbery and flowers; also that the flume shall be covered with a neat and substantial walk that will be available to the public, said walk to be painted and at all times kept in good repair ... And provided also that an amount of water shall be left to flow through the Park, that will always keep the stream at its present stage, or higher. ... ${ }^{46}$

The chamber's reversed opinion and its detailed insistence for protection of Macleay Park revealed that members were conflicted between their desire to safeguard the park and the alluring vision Pence offered of an industrial district that might bring more economic growth to the city.

\footnotetext{
${ }^{46}$ Resolution of the Portland Board of Trade, 1905, Council Documents - Parks, COP Archives; The Portland Chamber of Commerce to Geo. H. Williams, Chairman Committee on Parks, City, 17 May 1905, Council Documents - Parks, COP Archives; The Portland Chamber of Commerce to Geo. $\mathrm{H}$. Williams, Chairman Committee on Parks, City, 29 May 1905, Council Documents - Parks, COP Archives.
} 
In June 1905, during the height of the Lewis and Clark Exposition, Hawkins and the majority of parks commissioners denied Pence a permit, determining that the Pence Company could not "appropriate any of the water of Balch Creek for commercial purposes." ${ }^{47}$ Pence temporarily stopped work, but soon violated the park commissioners' resolution and built several thousand feet of his three-foot wide wooden flume system through Macleay Park. When city officials discovered Pence's transgression in February 1906, Mayor Harry Lane took dramatic action. Lane was a reformer best known for his two terms as mayor for routing out the poor workmanship of city contractors by "tapping all sidewalks and curbs" and hitting "the hollow ones open with a hammer." ${ }^{48}$ In keeping with his smashing reputation, Lane led a contingent of policemen with sledgehammers up to the hills and ordered them to destroy twenty feet of the flume, which unfortunately turned out to be a section outside of the park grounds. In a bombastic interview with the Oregonian, Pence presented a myriad of arguments his defense - ranging from assertions that Donald Macleay's intended development when he gifted Macleay Park to the city to insinuations that Hawkins' real interest was tied to his own hillside property. Hawkins was a part owner of the Ibex Land Company, which owned land adjacent to Macleay Park and refused permission for Pence's flumes to cross its property. ${ }^{49}$ Despite the public rancor exhibited between Lane and Pence, the men were soon conciliatory and exchanging friendly banter. The day after ordering the flume

\footnotetext{
47 "Flumes nor Pipes in Macieay Park," Oregon Journal, 15 June 1905, 8.

48 Johnston, 32.

49 "Historic Timeline," Portland Parks and Recreation.

http://www.portlandparks,orlg/History/History 1852-1900.htm, (7 October 2005).
} 
destroyed, Lane agreed that Pence's project would be of public benefit, but contended that he still needed a permit from the parks board. Like members of the Chamber of Commerce, Lane changed his mind - perhaps because filling Guild's Lake fit his progressive ideals. Historian Robert Johnston asserts that progressive era populists believed that land should be developed - not held by wealthy speculators - because development led to "more jobs (and) more land available for the poor." ${ }^{50}$ Lane urged the board to grant Pence a permit, stating that the city needed to encourage investors and development.

The trouble has been all along that whenever anybody came to Portland with money to invest, he has been met with all kinds of discouragement, and by this process we have seen Seattle grow up at our expense.... in the future, if I find that somebody wants to come here with a legitimate enterprise, I am going to tell him that the people are yearning for his presence, whether it is true or not, and I am going to do all in my power to invite capital and enterprise to this city. ${ }^{51}$

The parks board eventually granted Pence his permit in February 1906, with Hawkins dissenting. Hawkins died unexpectedly the next month. ${ }^{52}$ While this did not end Pence's conflicts within Portland, public attention turned to the lucrative real estate potential of his plan.

Investors seemed to like Pence's vision, and real estate transactions increased in the area. In December 1905, after the Lewis and Clark Exposition had closed, Seattle businessman John McMillan, and unnamed eastern and western investors,

\footnotetext{
50 "Smashes Flume of Lafe Pence," Oregonian, 26, February 1906, 1; Johnston, 160.

51 "Truce May End Fight of Flume," Oregonian, 27 February 1906, 10.

52 "Gets Flume Permit," Oregonian, 28 February 1906, 18; Portland Parks and Recreation, "Historic Timeline," http://www,portlandparks.orlg/History/History 1852-1900.htm, (5 October 2005).
} 
joined with Pence in an unclear business relationship and purchased the remaining exposition buildings and approximately seventy acres of the former fairgrounds. McMillan, who formed the Portland Development Company, had close ties to the railroad industry and had discussions with several local and national lines about service to his investors' Guild's Lake land. He served on the board of the Washington State Railway Commission and the National Railroads Commissioners Association. When the deal was made public, Pence told the Oregonian that some of the "white city" could be saved because fair buildings could be used for factories. He planned to supply the factories with water "direct from its reservoirs in Balch Basin." 53 In March 1906, Pence invited landowners and investors to an exhibit of his "hydraulic giants" at work, stating: "The Pence Company is now prepared to demonstrate its ability to fill the lands lying in and under Guild's Lake to any desired grade."

Soon, real estate speculation was in full force. Pence himself bought 100 acres at Guild's Lake for $\$ 140,000$. United Railways, which the Northern Pacific and Great Northern jointly acquired in 1910, purchased 200 acres of Guild's Lake land for more than $\$ 200,000$, with plans for a future railroad terminal. ${ }^{55}$ In addition, the Oregon Navigation and Rail Company and the Northern Pacific Railroad both owned significant amounts of submerged lands on the river side of Guild's Lake. Percy Blyth, who had been selling land he purchased from the Scottish-American Investment Company on Willamette Heights since the 1890 s, continued to be an active realtor.

\footnotetext{
53 "Fair Site Bought for Factories," Oregonian, 25 March 1906, 1.

54 "Will Meet Pence," Oregonian, 26 March 1906, 8.

55 "Russell and Blyth to Buy Great Tract," Oregonian, 9 March 1907, 16; "Greater Portland an Assured Fact," Oregonian, 25 February 1906, 30.
} 
Between the beginning of 1904 and the end of 1907 , he sold at least thirty-four hillside lots. In addition, Blyth and his business partner Lewis Russell bought roughly 650 hillside acres extending north of the fairgrounds from the Scottish-American Investment Company for $\$ 230,000$, a price the Oregonian described as "very reasonable." They contracted with the Pence Company to level the land for residences. The purchase made the partners one of the largest landholders in Portland. The Oregonian reported that:
Russell and Blyth believe expansion of the city will continue north and northwest and it is for this reason they acquired the land.... among other things that are expected to enhance the value of the property is the proposed electric line to be constructed by Lafe Pence along the hills toward Linnton. ${ }^{56}$

In early 1907, it appeared that Pence was progressing with his scheme despite "all sorts of legal obstacles, the protests of nearby property owners and the doubts of many people who did not believe his plans were practical." Pence had built extensive flumes and canals west of Balch Gulch, extending fourteen miles behind existing Willamette Heights homes near the Thurman Street Bridge. His workers had begun washing away the south side of "Scotch Nubbins," a large natural knoll that sat on the northwest side of Balch Gulch, several blocks behind existing Willamette Heights homes near the Thurman Street Bridge. Pence reported that during the favorable winter rains, his company had already transported 200,000 cubic yards from the knoll to two different properties on the edges of Guild's Lake. One was the peninsula on

\footnotetext{
${ }^{56}$ Direct Deed Index, Multnomah County Records; Indirect Deed Index, Multnomah County Records; "Russell and Blyth to Buy Great Tract," Oregonian, 9 March 1907, 16.
} 
Guild's Lake, known during the exposition as "Government Island." The company contracted with the peninsula's owner, the Reed Institute, to extend the property's dry land by twenty-eight acres. When the rains diminished, Pence planned to complete the work through "dry grading."

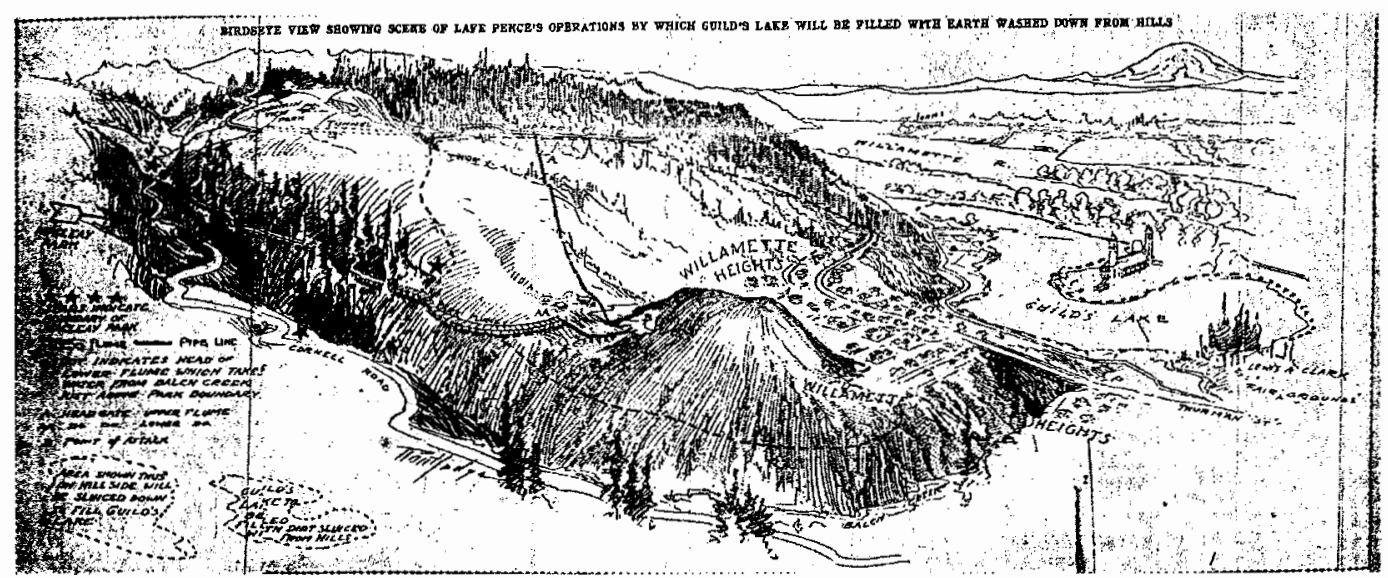

FIGURE 3: Illustration taken from the Oregonian, 1 March 1906, p.1.

Just when it appeared Pence's big plans had taken off, however, a banking panic and scandal derailed him and marked a brief end to a boom that E. Kimbark MacColl has described as being "built upon optimism and extended credit." In November 1907, the Title Guarantee \& Trust Company, a bank that financed Pence's operations and real estate holdings and those of the Portland Development company, "collapsed with a thud." The problem, as with other banks nation-wide, was that the company owed more money than it possessed, and could not meet depositors requests for withdrawals. In his characteristic dramatic fashion, Pence accused TG\&T officers of swindling him. And, in an unrelated matter, the police briefly sought Pence for allegedly posting a worthless $\$ 10,000$ bond to bail out a 12 -year-old boy accused of murder. Pence blamed his financial problems in part on low and unpredictable

57 "Pence's Dreams are Coming True," Oregonian, 11 March 1907, 12. 
rainfall, which apparently prevented him from ensuring potential customers of early completion of work. The operation relied upon rain to fill the creeks and reservoirs, which powered his giant hoses. In 1908, Pence left town having failed to fulfill contracts for sluicing the hills and filling the lake. ${ }^{58}$ The job of altering the area's landscape languished until 1909, when a new company stepped in with the goals of creating an aesthetically pleasing and profitable housing development and filling in Guild's Lake for industries.

The Seattle-based Lewis and Wiley Hydraulic Company took over the hillside development and lake filling projects in the summer of 1909 , when partners William Lewis and Charles Wiley bought eighty acres of Goldsmith Hill, east of Balch Gulch, and a large section of the gulch below Macleay Park. Lewis and Wiley also bought forty acres on the southern edge of Guild's Lake, in an area that was seasonally inundated with water. Lewis and Wiley soon contacted John Olmsted and asked him to help them design an attractive and profitable residential district. The partners wished to create an aesthetically beautiful project that would "harmonize with the probable growth of the city." Nonetheless, Lewis and Wiley soon sacrificed many design features in favor of a short-term profit. ${ }^{59}$ In addition, Macleay Park again became the center of tension between public good and private profit as Lewis and Wiley considered filling much of lower Balch Gulch to extend their residential district.

\footnotetext{
${ }^{58}$ MacColl, The Shaping of a City, 354-355; "Pence says Ross Tried to Ruin Him," Oregonian, 21 August 1908, 11; "Still Search for Pence," Oregonian, 15 August 1908, 16.

${ }^{59}$ Olmsted, notes, 16 December 1909, Lewis and Wiley Subdivision; Charles Wiley to John Olmsted, 10 August 1909, Lewis and Wiley Subdivision, Reel 223, Papers of the Olmsted Associates, Library of Congress.
} 


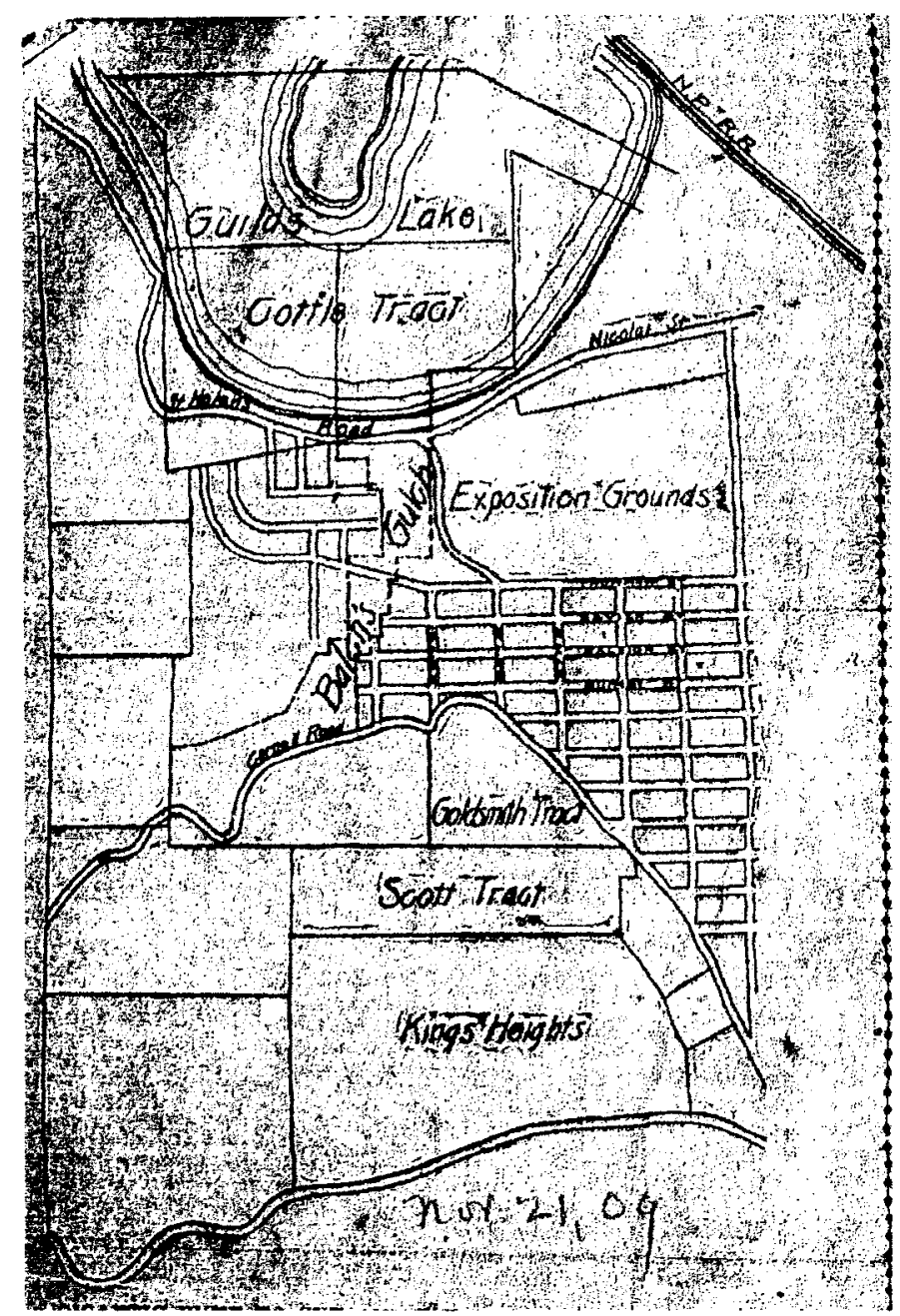

FIGURE 4: 1909 map found in an unidentified newspaper clip in a scrapbook belonging to George Himes, Scrapbook \#55, p. 24. Oregon Historical Society.

Lewis and Wiley brought experience and credibility to the sluicing project.

The contractors had been using hydraulic force to regrade much of Seattle, in projects led by Seattle's city engineer R.H. Thompson. A Portland banker, identified in the Oregonian as "Receiver Howard," who assumed receivership of failed property investments from Pence's project, assured Portlanders that Lewis and Wiley were reliable. He indicated that the filling projects might become more extensive:

They are men of the very highest type, and are supplied with money with which to execute their undertakings. 
The extent and character of their work in Seattle furnishes an illustration of what these men are doing on way of developing cities wherever they locate and operate. I am confident that the improvement which is to be done by these men here will prove only the beginning of extensive operations of the same nature, extending possibly from Guild's Lake to Linnton. ${ }^{60}$

Lewis and Wiley began their project with ideals of facilitating city growth and creating a beautiful neighborhood that would be protected by restrictions on building heights, livestock, and street-side garages:

It will be sold subject to such rigid restrictions as will benefit the property and protect the purchaser without complicating the title. Hard-surface pavements, cement sidewalks, sewers and other improvements will be installed and no expense will be spared to made (sic) the addition one of the most attractive residence districts to be found anywhere in the United States. ${ }^{61}$

Furthermore, Lewis and Wiley claimed that they would "conform strictly to the plans and recommendations" of Olmsted:

He will have a free hand in this respect and it is undoubtedly, the first time a landscape architect was ever given the opportunity to carve out a large addition and arbitrarily fix every grade. ${ }^{62}$

The contractors told Olmsted that their plan was ambitious, but that a high demand for property and the technology of hydraulic giants that allowed them to move earth inexpensively made it possible. Olmsted agreed to the work and soon immersed himself in details concerning street curvatures, appropriate grades, blending with other developments, land values, and the amount of excavations and fills needed. On a visit

\footnotetext{
50 "Hill, Cut Down, to Fill Guild's Lake," Oregonian, 19 November 1909, 14.

${ }^{61}$ Ibid.

${ }^{62}$ Ibid.
} 
to Portland, Olmsted personally examined the hillside property and met with a number of realtors and land developers. ${ }^{63}$

Lewis and Wiley's financial solvency was not quite as sure as had been reported. The funding of their operations was dependent on a number of contingent and speculative calculations. They needed a large amount of capital for their work, and hoped to raise some money as the project progressed by selling some of the lots early. The boom-bust nature of the real-estate economy in Portland was also a factor as projections of land value were dependent on a fluctuating market. The contractors ran into financial hurdles when the land boom slowed in 1910 and they were unable to sell the lots. Lewis told Olmsted that some potential buyers thought the hillside property was "too far out, too expensive, and lacked transportation." Olmsted went over the finances of the project, calculating expected expenses for excavating and filling, taxes for city amenities such as streets, and possible sale prices. Although Lewis and Wiley originally planned on including a street railway in their development, it never materialized. They were also unable to sell Guild's Lake lots. Lewis and Wiley faced problems when some owners of land the company wanted to purchase for their hillside development asked exorbitant prices. Lewis informed Olmsted that banks were unwilling to grant a loan for the project, and that they were pursuing private loans. Olmsted modified his plan for increased profits, but ultimately the

\footnotetext{
63 “Hill, Cut Down, to Fill Guild's Lake," Oregonian, 19 November 1909, 14; Olmsted, notes, 16 December 1909 and 20 December 1909, Lewis and Wiley Subdivision.
} 
company rejected many of Olmsted's suggestions in favor of ideas that could accommodate a faster construction schedule. ${ }^{64}$

Olmsted's early plans called for an eighty-foot entrance street and sixty-foot streets throughout the development. He also platted 120 -feet-deep lots that were set in pairs on wide terraces. Olmsted's streets were on either side of the terracing, with driveway access on up and downhill sides of the properties. Because Olmsted was not readily available for consult and they wished to move quickly on their work, however, Lewis and Wiley rejected many of Olmsted's suggestions and employed another engineer, Claude Ott. Ott's plan increased the number of lots from about 233 to 314 by narrowing lots to 100 -feet and streets to sixty and fifty-foot widths. Unsatisfied with Ott's street arrangements, Olmsted amended his plan with the adjustment, but reworked Ott's street layout, which he complained was awkward, with too many zigzags and a main street with "a number of wiggle waggles." Even though Olmsted's new plan allowed for an increase to 330 lots, the contractors had already moved ahead with Ott's plan. Olmsted noted that Lewis:

Said their engineer had reported that the grading had gone too far to abandon his plan in favor of ours as respects the layout where we shortened the main avenue. I believe he is making a mistake as we get more lots and fewer running street to street, shorter route for the trunk thoroughfare, shorter and less expensive car tract and better relation of lots to view. ${ }^{65}$

\footnotetext{
${ }^{64}$ Olmsted, notes, 1 January 1910, 17 March, 1910, 20 May 1910, 2 June 1910, 13 June 1910, Lewis and Wiley Subdivision.

${ }^{65}$ Olmsted, notes, 8 October 1911 , Lewis and Wiley Subdivision.
} 
In the end, one of the more significant of Olmsted's ideas that Lewis and Wiley kept was to save topsoil during the sluicing process for reuse in the hillside neighborhood. ${ }^{66}$ Despite that accommodation, Lewis and Wiley's desire to capitalize on a capricious Portland land boom led to sacrifices in their earlier plan to put aesthetical beauty as one of the primary goals for their development. Economic priorities trumped artistic values.

The conflict in values between public versus private good again came into play with Lewis and Wiley's property in Balch Gulch, which sat on the northern boundary of Macleay Park. Today Macleay Park extends north through Balch Gulch, terminating just north of the Thurman Street Bridge, which links the Willamette Heights neighborhood to the city. Balch Creek runs north through the gulch until the bridge, where it goes into an underground conduit to the Willamette River. In 1910, Macleay Park was a rectangular-shaped plat farther south on Cornell Road, with a northern boundary about seven city blocks south of where it is today. At that time, Lewis and Wiley owned a tongue-like extension of Balch Gulch to the Thurman Street Bridge. Many Portlanders wanted the parks board to purchase that land -- twentyseven acres -- as an extension for the park. Lafe Pence had eliminated easy public access to the park in 1906 or 1907, when his company built flumes and hydraulic operations west of the Forestry Building, and below the bridge. ${ }^{67}$ Although Lewis and Wiley negotiated with the city to sell the gulch land, they strongly considered keeping

\footnotetext{
${ }^{66}$ Olmsted, notes, 12 June 1911, 12 June 1911, Lewis and Wiley Subdivision; John Olmsted to William H. Lewis, 28 July 1911, Lewis and Wiley Subdivision.

${ }^{67}$ Roswell B. Lamson, Attorney, to the Honorable Mayor and Park Board, 1 April 1910, Council Documents - Parks, COP Archives.
} 
the property and filling it with sluice material to create more saleable residential lots.

The ravine was conveniently close to the area where Lewis and Wiley planned to remove earth. Their idea to fill the gulch from Macleay Park to NW Thurman Street found some approval in Portland. City engineer J. W. Morris told Mayor Joseph Simon that it could be beneficial to the city:

I have Mr. Lewis's assurance that they are going to fill the gulch entirely and up to the level of the Thurman Street Bridge. By doing so, we will be able to remove this bridge which was none to substantial in the beginning and which is rapidly approaching the dangerous stage. By saving the City the cost of renewing this bridge, a matter of $\$ 60,000$ or $\$ 75,000$, I think that Lewis and Wiley are conferring a decided public benefit to the taxpayers at large. By filling up Balch's Gulch, it impresses me that they are conferring a decided favor upon the residents of that vicinity by removing a deep and utterly useless gulch, and making out of it sightly residence property. ${ }^{68}$

Despite the support of the city engineer, Lewis and Wiley were aware that their filling plan angered Portlanders who wanted the gulch added to Macleay Park. ${ }^{69}$ Park proponents argued that Lafe Pence's flume works had destroyed the commonly used entrance to the park, from the former fairgrounds, and that it had become difficult for park goers to find access. C.W. Sherman, who had opposed Pence's flume, urged park commissioner J.R. Weatherbee (who also owned hillside land) to buy the property for the city:

Every day people residing on Willamette Heights are asked for directions and instructions as to how to reach

\footnotetext{
${ }^{68} \mathrm{~J}$. W. Morris to the Honorable Joseph Simon, 25 May 1911, Joseph Simon Papers, General Correspondence, COP Archives.

${ }^{69}$ Olmsted, notes, 13 June 1911, Lewis and Wiley Subdivision.
} 
Macleay Park. There is not suitable or practical entrance at the present time ... the thing that I would strongly urge is to acquire an entrance up from the Forestry Building through the old Italian Garden and up the bottom of the Canyon to the park. This undoubtedly should have been done long ago, but it is not yet too late. $^{70}$

Other citizens who wrote to Weatherbee to support purchasing the gulch mostly agreed with Sherman. Although one Willamette Heights resident, Sanderson Reed, questioned the viability of this private project and complained that the Lewis and Wiley Company had dammed the creek under the Thurman Street Bridge, creating a thirty-foot-deep lake:

During this summer it will be a green, slimy hole and is not $a$ benefit from any standpoint ... if the work is discontinued we will have a stagnant pond which will be a menace to the health of the people of this neighborhood and dangerous to the children by reason of the fact that it is in a very steep canyon. ${ }^{71}$

In 1909 , the city successfully pursued plans to buy ravine property. ${ }^{72}$ Park Superintendent E.T. Mische then studied linking the two-acre Forestry Building park to the gulch, possibly with a "main park drive to be constructed through Macleay Park." ${ }^{, 73}$ The proposal to put a road through the park was first recommended in Olmsted's 1903 parks report. It was never implemented, perhaps because of citizen

\footnotetext{
${ }^{70}$ C.W. Sherman to J.R. Weatherbee, City, 31 August 1909, Council Documents - Parks, COP Archives.

${ }^{71}$ Sanderson Reed to Hon. Joseph Simon, 11 May 1911, Joseph Simon Papers, General Correspondence, COP Archives.

${ }^{72}$ A city representative contacted owners of property in the ravine property and found that many were willing to sell at low prices. Roswell B. Lamson, Attorney, to the Honorable Mayor and Park Board, 1 April 1910, Council Documents - Parks, COP Archives.

${ }^{73}$ E.T. Mische, Report to the Parks Board, 3 December 1909, Council Documents - Parks, COP Archives.
} 
objections. Portlander Edith Nicholson told park commissioners that clearing the natural landscape for an "Automobile Road" would harm the park's wild charms:

To follow the winding trails, as they existed previously, was to be admitted into the heart of Nature's charms; mosses and ferns flourished unmolested; the stream with its pools and falls furnishing the needful moisture to keep them. ${ }^{74}$

Lewis and Wiley succeeded in creating the Westover Terraces neighborhood and a fifty-acre industrial center on the edge of the fairgrounds and a portion of filledin Guild's Lake shore land. Sales at Industrial Center picked up, and many investors bought for short-term speculation. The Oregonian lauded the filled in land:

Quietly and without ostentation, during the past two and a half years, Guild's lake has been transformed from a muddy and unattractive sheet of water into a modern upto-date industrial center ... For many years the consensus of Portland opinion has been that some day Guild's lake would be the manufacturing district of Portland. Everybody realized that it would be a huge undertaking to transform this body of water into dry land, but that it would be done some day no one doubted. $^{75}$

In 1915 , an investment syndicate bought fifty-six of the ninety-two lots in the vicinity of The Trail at the former fairgrounds. The Oregonian reported that the Industrial Center had "splendid railroad accommodations, with switching and access tracks run through alleys to each lot:

The platting plan of the property is along the lines of the latest and most efficient ideas that have been

\footnotetext{
${ }^{74}$ Olmsted, Report of the Park Board; Edith Nicholson to the Hon. Parks Board, 31 March 1910, Council Documents - Parks, COP Archives.

75 “Guild's Lake Quietly Transformed Into Industrial Center," Oregonian, 28 September 1913.
} 
inaugurated in the industrial sections of the largest Eastern cities. ${ }^{76}$

Although Industrial Center sales appeared to be good, Westover Terraces sales lagged despite the optimism that Lewis expressed to Olmsted in 1912, when he reported they had completed seventy-five completed lots that were "selling rapidly."77 According to historian E. Kimbark MacColl, Westover Terraces and nearby hillside developments all suffered from financial difficulties, and did not see profit until the 1920s:

They provided a good example of the inherent risks of real estate investment, the importance of timing and the need for patience. Solid financial underwriting was essential. $^{78}$

Deals with area property owners did not solve the problem. Lewis and Wiley funded their operation in-part with contracts to sluice and fill neighboring property, including the proposed "Blytheswood" hillside development northwest of Willamette Heights and flat marshland owned by near the Industrial Center owned by United Railways, but those deals were not enough to ensure financial stability. MacColl contends that Lewis and Wiley were indebt by $\$ 391,000$ from bonds they had sold to finance operations - debts that were later assumed by Portland's Ladd \& Tilton bank. ${ }^{79}$

Lewis and Wiley carved out a new landscape, but nature was not quietly compliant. The developments suffered from drainage problems and the new hillside neighborhoods above Guild's Lake were plagued with landslides. In 1910 City

\footnotetext{
76 "Industrial Center Deal Tops Mart," Oregonian, 7 March 1915,

${ }^{n}$ William Lewis to J. C. Olmsted, 20 January 1912, Lewis and Wiley Subdivision.

${ }^{78}$ Ibid.

${ }^{79}$ MacColl, The Growth of a City, 77, 206.
} 
Council passed a law requiring property owners in the Willamette Heights Addition to maintain retaining walls, and in 1912 the city built retaining walls to protect Westover and Cumberland Roads. In the 1920 s, the city documented more than thirty slides, some including fill material, in Westover Terraces, Willamette Heights, and Blytheswood. In the 1930 s, responding to problems of flooded basements, city used federal Works Progress Administration grants to build French drains in Willamette Heights. $^{80}$

${ }^{80}$ City Council Minutes, 23 March 1910 and 9 October 1912, COP Archives; "List of Slides in Streets of Westover Terraces, undated, City Engineer's Historical Records, COP Archives; Ormond R. Bean, Commissioner of Public Works to Works Progress Administration, 4 March 1938, WPA Project 1972, 1938-1939, COP Archives. 


\section{Chapter Three}

\section{Planning an Industrial District: The Port of Portland and Landowners Cooperate}

Water continued to define Guild's Lake and to affect Portlanders' efforts to create dry land. A nearly ten-year effort filled fifty acres, but most of the shallow, flood-prone marsh remained. The failure of Lafe Pence and the Lewis and Wiley Hydraulic Company to eradicate Guild's Lake showed that development efforts would require the involvement of more landowners, cooperative planning, and a large source of funding. During the late 1910s, these elements came together with a renewed effort to create a landscape to better serve perceived community needs. Early twentieth century ideas about planning influenced city builders to think broadly about how to alter the city's physical landscape for increased business and trade. Filling efforts at Guild's Lake intertwined with Port of Portland plans to increase commercial shipping in the Willamette River harbor. In 1919, business leaders produced a comprehensive plan for port and wetlands development that required greater efforts to justify the use of taxpayer money. Although proponents argued that the city as a whole would benefit, business-class priorities drove the project. In addition, debates about the role of government in planning, funding, developing, and owning real estate became central as supporters of the project sought to unify divided interests. While a publicly owned landscape at Guild's Lake failed to win needed political support, determined landowners continued to pursue a cooperative approach. The nature of low-lying wetlands made it difficult to fill and develop parcels with out affecting neighboring land. Property owners also wanted to work together to fulfill their vision of an 
industrial area that offered businesses unified transportation amenities. In the end, the port and Guild's Lake landowners succeeded in filling Guild's Lake and adjacent wetlands. They encountered difficulty, however, in convincing their fellow property owners to work collectively.

In the late 1910s, somewhat in contrast to the earlier effort to fill Guild's Lake with hillside dirt, new plans to fill the remainder of the lake stemmed from attempts at cohesive city planning. Professional and lay planners looked for ways to comprehensively alter Portland's cityscape for increased trade and manufacturing. Olmsted's 1903 park plan reflected the national aesthetic trends of City Beautiful, but later city plans followed evolving trends to make urban landscapes more rational and economically prosperous. In Planning the Capitalist City, Richard Foglesong argues that City Beautiful lost ground to the business-oriented City Practical because it responded more clearly to the needs of business interests, rather than the more aesthetic ideals of the architects and landscape architects who had initiated city planning in the United States. Foglesong, who uses a "Marxist view to elucidate the meaning" of American planning, contends that planners catered to capitalist interests because businessmen were the main supporters of their burgeoning profession. Business leaders wanted city landscapes that better facilitated manufacturing and trade with coordinated patterns of roads, railroads, and ports. Many land owners and real estate speculators were also interesting in using zoning laws to enhance property values. Proponents of City Practical wanted to segregate factories into industrial areas, where they could be effectively served by railroads and ships, and also sought to 
shield higher-end residential districts from manufacturing and industrial pollutants. ${ }^{1}$ In Portland, the first efforts at city planning blended elements of City Beautiful and City Practical.

Near the end of the first decade of the twentieth century, businessmen and realestate developers in the Civic Improvement League hired city planner Edward Bennett to create a vision for Portland's future. In his 1912 Greater Portland plan, Bennett recommended that city leaders plan parks, streets, urban centers, and transportation networks to serve "convenience, utility and beauty." He argued that the built urban landscape should be rational:

The ideal is the organic city with its parts and activities closely related and well defined, but not conflicting; wisely and economically builded (sic), not a cluster of villages, each with its center, and with boundaries accidentally merged.

Bennett compared cities to living bodies and advocated segregating the city into zones with well-arranged transportation "arteries" that would be the "channels for the life blood of the City." The plan called for harbor improvements and suggested many alterations that became central to Portland planning in years to come, including a deeper and wider river channel, more docks and rail connections, and the creation of industrial land downriver from the city center. At Guild's Lake, Bennett recommended the city connect Swan Island to the west side of the channel with a landfill and cut large shipping slips and docks into the marsh. ${ }^{2}$ Although city voters

\footnotetext{
${ }^{1}$ Foglesong, 199-215, 251.

${ }^{2}$ Edward H. Bennett, The Greater Portland Plan. Portland, Oregon, 1912. Planning Documents, COP Archives.
} 
approved the Greater Portland Plan in 1912 municipal elections, the ballot measure did not approve any funding. In 1913, a regional depression dramatically slowed construction in Portland, and Greater Portland plans stalled -- along with ideas for further landscape change at Guild's Lake. ${ }^{3}$

City Practical continued to influence Portland after the economy rebounded in 1918. World War I spurred a boom in Portland as numerous shipyards sprung up to meet wartime demands. An influx of workers caused a city housing shortage, leading a state-appointed Housing Survey Committee to hire planner Charles Cheney to study the problem and create a comprehensive city plan. Cheney reported that "progressive city governments" chose where to locate residences, businesses, and factories, and avoided letting land uses intermingle because "the intrusion of the garage, laundry and apartments into home neighborhoods, is not only unnecessary, but actually causes the depreciation of millions of dollars of adjoining property."*4 Like Bennett, Cheney sought to bring efficiency and cost-effective organization to Portland's industrial development through "linked up" transportation networks and utilities. In addition, he reported to the committee a poll of local businessmen showed more land was needed for industrial development. One industrial employer told Cheney that a scarcity of cheap land could cause the company to relocate to another city.

In our survey of the land at the river waterfront, we find that it merely consists of a series of swamps and overflow land, and our opinion is that it will have to be bulkheaded and filled in before industries of any magnitude locate here which desire waterfront. This frontage, in our

\footnotetext{
${ }^{3}$ Abbott, Portland, 67.

${ }^{4}$ Charles Cheney, Report to the City Planning Commission. Portland, June 1919. Planning Documents, COP Archives.
} 
opinion, is held at fancy prices, and unless something is done, either in filling or scaling of prices, it will be a long time before the riverfront is utilized. $^{5}$

Cheney suggested that while Portland had scattered industries, special zones should be created to consolidate factories with coordinated services and rail and river transportation facilities. He argued that the city, the Portland Docks Commission, the Port of Portland, railroad companies, and "industrial managers" could save money by sharing expenses for amenities, including railroad spur tracks, "elevated sidewalk delivery platforms," and fire protection.

Portland citizens worked in conjunction with Cheney in city planning, and contributed suggestions about how and where industrial development should take place. In 1918, Mayor George Baker and the city council augmented Cheney's work by appointing men representing business, trades, realty interests, and builders to the city's first official planning commission. The Planning Commission members were to serve as advisors to the city government. Supporters of the planning commission included members of Portland's most elite class, large property owners, bankers, and business leaders who liked zoning because it could protect property values. ${ }^{6}$ In his work, Cheney strongly emphasized the importance of segregating land use to land values.

Individual property owners are helpless to prevent these intrusions and the depreciation of their property. The establishment of a zone ordinance will do for individual owners what they cannot now do for themselves - set up

\footnotetext{
${ }^{5}$ Cheney, Report to the City Planning Commission.

${ }^{6}$ Abbott, Portland, 80.
} 
uniform restrictions that will protect each against his neighbor, and thus be a benefit to all. ${ }^{7}$

Isolating factories into their own district was an important aspect of this philosophy.

A commission subcommittee specifically examined where to create zones for industry and manufacturing. Members looked at establishing building height restrictions, excluding residential buildings, and suggesting property owners work together to create useful infrastructure, including:

Wide pavements suitable for heavy hauling, extra large sewers for industrial waste, extra high pressure fire protection systems, and large water mains, ample spur tracks, crossing sidewalk lines when required, closing of streets unnecessary for through traffic, high tension power lines, permanent and convenient location of freight depots, steam railroad tracks and classification yards. $^{8}$

The committee recommended that two types of industrial zones be created, one for "ordinary, but not obnoxious factories, warehouses and industries," and another for "obnoxious and odor producing factories." Committee members suggested the zones be located mostly in low-lying areas near the Willamette River, including some already dry land near Guild's Lake, and on the Columbia Slough. ${ }^{9}$ Most Portlanders, however, did not support zoning. Abbott finds that small property owners and some realtors opposed zoning because it "blocked the natural growth of the city and benefited a few land tycoons at the expense of the middle-class landowners."

\footnotetext{
${ }^{7}$ Cheney, Report to the City Planning Commission.

${ }^{8}$ Subcommittee members to J.P. Newell, President of the City Planning Commission, 24 October 1919. Planning Documents, COP Archives.

${ }^{9}$ Ibid.
} 
Consequently, it took four years for city voters to approve a watered-down version of city zoning. ${ }^{10}$

In addition to trying to establish zoning, Portland's business leaders worked to reshape the Willamette River and Swan Island to accommodate more commercial shipping. While Portland had a thriving port, E. Kimbark MacColl writes that growing trade competition from Puget Sound threatened Portland's status as the "leading dry cargo port on the West Coast," and prompted the city's politicians and businessmen to take action. ${ }^{11}$ Since the late nineteenth century, U.S. Army Corps of Engineers officers had complained that the Willamette River's shipping channel east of Swan Island was tortuously narrow and crooked. The channel on the west side of the river was wider, but also shallower. In 1876 and 1877, Major John Wilson recommended closing the eastern channel with a dike and dredging the western channel, but his superiors did not approve the project. ${ }^{12}$ Roughly thirty years later, the Portland Docks Commission and the Port of Portland both contemplated buying Swan Island and moving the shipping channel. In 1913, the Portland Docks Commission, which Portland voters formed three years earlier to build and maintain public docks, sought to purchase Swan Island to remove it. The docks commission wanted to deposit dredge spoils into the adjacent Mock's Bottom wetlands on the eastern bank of

\footnotetext{
${ }^{10}$ Abbott, Portland, 82-87.

${ }^{11}$ MacColl, Growth of a City, 213-216.

${ }^{12}$ U.S. Army Engineer, District, Portland Corps of Engineers, The History of the Portland District Corps of Engineers, 1871-1969. Portland, Oregon, 1970, 22-23.
} 
the Willamette River, "thus giving better harbor facilities to the city of Portland."13 In 1919 , the port took up the cause after fifteen years of consideration. The port, which the state legislature had created in 1891 to deepen and maintain a shipping channel to the sea, also wanted to move the shipping channel from the east side to the west side of Swan Island. The move was necessary, as the Oregon Journal later explained, because "ocean going vessels" using the deeper east channel had to make a turn at "Mock's bend," and only "log boats" could use the shallower west channel. ${ }^{14}$ Swan Island's owners, who included William Sherlock and Simeon Reed, had incorporated the island in 1889. They used the 270-acre island's riparian marshes for duck hunting, but viewed the property primarily as an investment. In 1906, they offered it for sale for $\$ 200,000$. In 1913 , when the docks commission was considering purchasing Swan Island, the owners asked the relatively steep price of $\$ 525,000 .{ }^{15}$ While high prices may have put purchasers off, port and dock commissioners did not abandon their plans for Swan Island.

In the spirit of Cheney-inspired city planning, city leaders worked with port and dock commission members to expand their plans for alterations to the Willamette River. In 1919 Mayor Baker appointed a "Committee of Fifteen" to solidify the connection between port and industrial developments. The mayor asked committee

\footnotetext{
${ }^{13}$ F. W. Mulkey, Chairman of the Commission of Public Docks, to H. R. Albee, Mayor of Portland, 7 October 1913. Mayor Harry Russell Albee, Subject Files, Public Docks Commission, Swan Island, COP Archives.

14 "10,000 asked to Develop Port," Oregonian, 25 March 1920, 1; "New Channel Work Starts Next Monday," Oregon Journal, 9 December 1921, 1; "First Move on Terminal Made," Oregon Journal, 7 December 1921, 1.

${ }^{15}$ MacColl, Growth of a City, 233.
} 
members to work with the Port of Portland and the City Docks Commission to make a plan that would offer:

1. ... a satisfactory river channel and ample harbor and dock facilities.

2. Relief from railroad terminal congestion and ample rail terminal facilities.

3. Provision for ample and convenient sites for industrial development. ${ }^{16}$

The committee wrote a comprehensive plan to create a large, public landscape that tied together river channel deepening and landfills for new industrial areas. They concluded that the port and docks commissions should merge, buy Swan Island, Mock's Bottom, and Guild's Lake. Then the port could move and deepen the river channel and use the dredge spoils to fill low lands that were "right at hand," thus avoiding barging material elsewhere. ${ }^{17}$ By dumping the spoils into swamps on Swan Island, and at Guild's Lake and Mock's Bottom, city leaders argued the port would improve areas that were obstructing "the orderly development of Industrial activities in Portland."18 A key part of the plan was to merge the state-owned Port of Portland with the Portland Dock Commission - granting the port broader power to own land and to issue bonds for purchasing and development. While the port was a state agency, funding came from property taxes in the port district - roughly the Portland metropolitan area. The port would have then purchased Swan Island, Mock's Bottom,

\footnotetext{
${ }^{16}$ Committee of Fifteen, "A Report from the Committee of Fifteen on Proposed Developments at Swan Island," President Subject Files, Great Northern Railroad Company, MHS.

${ }^{17}$ Committee of Fifteen, "Plans for Waterways, for Terminals and Water Sites 1920," Vol. 2. Planning Documents, COP Archives; Robert G. Dieck, Advisory Engineer, "A Report on the Economic Elevation of Flood Protection Works at Portland Oregon," 13-16. Planning Documents. COP Archives. 18 "New Port Project to be Viewed Today," Oregonian 26 March 1920, 6; MacColl, Growth of a City, 213.
} 
and the low-lying land at Guild's Lake and adjacent wetlands to transform approximately 1,500 acres of land. The plan focused primarily on the merger and property acquisition, but committee members also suggested specific landscape alterations. They recommended that half of Swan Island be removed and that the remaining portion be connected to the east bank of the Willamette River. The eastern shipping channel would be replaced with a "mole," a basin where ships could turn, dock, load and unload. In the Guild's Lake district, committee members suggested that the port build docks and dredge large ship slips into the river bank. ${ }^{19}$

In their recommendations for development at Guild's Lake and Mock's Bottom, Committee of Fifteen members supposedly offered impartial advise to the city, however the all-male members advocated for their class and personal economic interests. The appointment of the semi-independent committee represented a national trend to legitimize city planning with government sanction while maintaining the domination of elite community members. Richard Foglesong writes that proponents of citizen committees argued they would provide a better comprehensive planning vision because unelected members were not affected by contemporary political storms. Foglesong contends, however, that these types of committees used class-based values and priorities to control the built environment.

Planning in this era became a legitimate function of local government; it was organized in the form of elite dominated local planning commissions insulated from institutions of popular control. ${ }^{20}$

\footnotetext{
${ }^{19}$ Committee of Fifteen, "A Report from the Committee of Fifteen on Proposed Developments at Swan Island."

${ }^{20}$ Foglesong, 11-22, 206-249.
} 
Furthermore, he writes that businessmen who controlled American city commissions "put forward their interest in rationalizing the system of land use and transportation for purposes of business and commerce as the truest expression of the city's collective interest." ${ }^{21}$ In Portland, E. Kimbark MacColl argues, the power class often acted in their own self-interest while in elected office or serving on citizen commissions. In Growth of a City, MacColl describes Portland's "first families" as a very wealthy group that made money through early investments in "transportation, utilities, insurance, manufacturing, and of course real estate." In 1919, he argues, this power class wanted growth, but were uninterested in social inequities. ${ }^{22}$

It is likely that Portland's elite business leaders did not distinguish much between their own interests and what they saw as the public's interests. In broad perspective, they wanted growth in city industries and trade to ensure continued economic prosperity. Visiting railroad executive D.J. Kerr reported that many Portlanders believed the Committee of Fifteen's plan would help the city maintain a competitive port with good transportation facilities to attract ships and businesses. Business leaders also regularly argued that inexpensive industrial sites were needed to attract new companies to Portland. To that end, Committee of Fifteen members argued that the public could gain economically through the sale or rental of filled in lands, and by "the creation of a great industrial center where the peculiar demands of

\footnotetext{
${ }^{21}$ Ibid.

${ }^{22}$ MacColl, Growth of a City, 5-6, 36-66.
} 
industries could be met in most orderly fashion." ${ }^{, 23}$ Member Fred C. Knapp said the plan to fill land would give the public a financial return and would attract businesses to Portland.

We want smokestacks and not swamps. We will be able to lease and give the city practically 6 percent or to the port, 6 percent upon its investment, an acre of land at one dollar, and when we get into shape with these facilities, rail and water, so we can give the small manufacture who wants to come here an acre of land for him to develop his business, on upon the basis of a rental of $\$ 1$ dollar an acre. ${ }^{24}$

Knapp's slogan of "Smokestacks and not Swamps" resonated with Port of Portland Commission president Frank Warren and Mayor Baker, who added that the city needed to make "progressive" moves in port development in order to avoid being "a spinster city." 25

Personal economic interests surely influenced Committee of Fifteen members. Knapp was a member of the docks commission and owned several river-dependent businesses, the Peninsula Lumber Company in St. Johns, and a World War I shipbuilding company. He also dealt in real estate. Frank S. Doernbecher, who died in 1921 , owned a furniture company that would have needed the city to maintain good rail and shipping facilities. Max Houser was the president of the Port of Portland Commission and owned a large flour mill on the Willamette River. In Growth of a City, MacColl paints Houser as a colorful player in the commodity markets who lost

\footnotetext{
${ }^{23}$ Abbott, Portland, 8; D.J. Kerr to R. Budd, Portland, Oregon, 31 March 1920, President's Subject Files, GNRC Records, MHS; Committee of Fifteen, "Plans for Waterways, for Terminals and Water Sites 1920," Vol. 2.

24 "Proceedings of the $1^{\text {st }}$ Annual Convention of the Northwest Rivers and Harbors Congress, Oct. 4-6, 1920." Government Records, Port of Portland, Oregon Historical Society.

${ }^{25}$ Ibid.
} 
all of his money through wheat speculation in 1920. Afterwards, he resigned from the port commission and stepped back from public life. Committee of Fifteen members William Cornfoot and St. John's developer E.J. Jaeger both traded in real estate and could have benefited from increased land values. ${ }^{26}$ Banker and committee chairman Emery Olmstead could have seen increased investment possibilities with the creation of industrial real estates. While conflicts of interest were often subtle, sometimes they were more overt. Olmstead, who was president of the Northwestern National Bank, had business partners who invested in Guild's Lake property the same year he was appointed committee chairman. He was later active in the Guild's Lake Landowners Association. MacColl writes that Portland's older establishment considered Olmstead to be sort of a rash upstart. Despite that assessment, Olmstead was an active community leader. During World War I, he demonstrated his patriotism by participating in the Liberty Loan Campaign. He also organized a recall of then U.S. Senator Harry Lane for opposing the war resolution, however, Lane's unexpected death ended the recall. Olmstead may have been respected as the chairman of the Committee of Fifteen in 1919, but he later faced scandal. In the late 1920s a jury convicted Olmstead for fraud for his actions during the financial collapse of his bank. He served two years in prison before being pardoned by President Herbert Hoover. ${ }^{27}$ Of the Committee of Fifteen members, James B. Kerr had the most blatant conflict of interest. As an attorney, he represented landowners at Guild's Lake and Swan Island. By taking a leadership role on the Committee of Fifteen, Kerr, who had

\footnotetext{
${ }^{26}$ Direct and Indirect Deed Indexes, Property Records, Multnomah County Records.

${ }^{27}$ MacColl, Growth of a City, 137, 147, 277, 378.
} 
also served on the planning commission's industrial subcommittee, was well positioned to help his powerful clients. Kerr was a Trustee of Reed College and lawyer for the Reed Institute, which managed the Reed estate for the benefit of Reed College. The Reed Institute owned significant acreage on Swan Island and at Guild's Lake. Kerr, who moved to Portland from St. Paul, Minnesota, several years after the Lewis and Clark Exposition, also worked as an attorney for the James J. Hill associated railroad companies - The Northern Pacific and the Great Northern.

In 1904 the U.S. Supreme Court used the Sherman Anti-Trust Law to break up Hill's unified control of those companies and the Burlington Railroad, and in 1916 Hill died. Despite that, the Great Northern and the Northern Pacific remained closely allied, and together co-owned subsidiaries in Portland, including United Railways, the Spokane, Portland \& Seattle Railroad, the Northern Pacific Terminal Company, and the Ruth Realty Company. Several of those subsidiaries owned property at Guild's Lake and had economic interest in all rail, industrial, and port developments in the area. Furthermore, the Hill-associated railroads had an interest in Guild's Lake rail developments because a competitor -- the Oregon-Washington Railroad and Navigation Company -- monopolized east side rail traffic. ${ }^{28}$

However Committee of Fifteen members each balanced private and public benefits of the plan, their proposals spurred public debates about the role of government in the project. State legislators presented the idea for a port and dock

\footnotetext{
28 "Hill, James Jerome (1838-1916)," The Online Encyclopedia of Washington State History, HistoryLink.org, http://www.historylink.org/essays/output.cfm?file_id=7294 (6 October 2005); D.J. Kerr to R. Budd, Portland, Oregon, 31 March 1920.
} 
commissions' merger to Oregon voters on the November 1920 ballot. The arguments for the merger focused on consolidating overlapping responsibilities and creating a more powerful Port of Portland. The agency could raise funds by issuing bonds, but it could only own land for direct shipping purposes. The dock commission could also issue bond, but it had broader ability to own land than the port. In the merger, the port would buy all dock commission property from Portland and also attain the ability to own and develop industrial land.

Some Portlanders opposed the measure because they believed it ceded the "home rule" of the city docks commission to the state government by allowing the legislature to approve up to $\$ 16.5$ million in bonds that would be the responsibility of taxpayers in the port district - the Portland metropolitan area. Port district taxpayers were responsible for the principal and interest payments on bonds. W.B. Ayer, president of the Eastern and Western Lumber Company, argued that "if the consolidated port and dock bill passes, the people of the port will have no right to determine themselves whether they should be burdened with a bond issue." ${ }^{29}$ The Portland Chamber of Commerce agreed with Ayer. In a resolution, the chamber complained that the state legislature would have the authority to approve bonds that local taxpayers were responsible for. In addition, opponents objected to the high costs of the project. Ayer, who also opposed the suggested six-year tenure of port commissioners, argued that moving the shipping channel was an unneeded expense.

\footnotetext{
${ }^{29}$ MacColl, Growth of a City, 235; "W.B. Ayer Gives Argument Against Swan Island Plan," Oregon Journal, 6 October 1920, 14.
} 
One of the most important objects aimed at in the bill is to close the channel on the east side of the Willamette River between Swan Island and the shore, and, at the cost of many millions of dollars, open up the west channel. The statement is made by many men long engaged in the shipping business that there has never been an accident in the east channel and that it can be further improved at comparatively small cost, while other people contend that it is not a good channel. ${ }^{30}$

The Oregon Journal also questioned the need for the Swan Island project, arguing that Portland had already spent $\$ 10.5$ million over ten years and that it had adequate port facilities to "meet the commerce needs of the port for years." The newspaper suggested that the city could better spend financial resources on maintaining a deeper Columbia River shipping channel. ${ }^{31}$

Former port president Max Houser also opposed the bill, saying the port should not become involved in a large real estate venture. Because of Houser's stature in the community, the Oregonian was careful not to attack him for his "misgivings." However, the newspaper urged Houser to reconsider, stating that Portland's growth was at a critical juncture.

Any policy which is adopted by the people of Portland at this time will decide the course of the city's growth for many years to come, for it will establish certain facts to which later improvements must be accommodated. A mistake might seriously delay, sting or distort its growth. ${ }^{32}$

Although the City Club of Portland approved of the plan to buy Swan Island and move the shipping channel, club members criticized the plan for being

\footnotetext{
30 "Chamber is Opposed to Island Bill," Oregon Journal, 16 October 1920, 1.

31 "The Port Bill," Oregon Journal, 8 October 1920, 8.

32 "A Combination of Benefits," Oregonian, 5 June 1920, 8.
} 
underdeveloped and for underestimating public expenses. The Committee of Fifteen report stated that river dredging and the acquisition and development of land would cost approximately ten million dollars, but the City Club report estimated that total costs would be $\$ 40.5$ million dollars. The report found that the Committee of Fifteen did not add the costs of building necessary infrastructure for industrial areas or constructing river bulkheads and docks. While Committee of Fifteen members acknowledged the large public costs, they contended that the public would reap financial benefits.

The only alternative ... would be to acquire from the upland owners merely the right to deposit the dredged material and in this even the vast increment of value arising from the filling of privately owned property at public expense would inure to the individual land owners. It is thought that a sound public policy would not justify such a gratuitous donation. Furthermore, the report ... fairly demonstrates that the net result of the proposed development will be to vest in the public title to a great area of land ideally adapted to use for industrial,, railroad and dock purposes of value greatly exceeding this total cost of the property, including its reclamation, and the whole channel and harbor development as well. ${ }^{33}$

The City Club also questioned the need for new industrial land, arguing that six to seven thousand ready-to-build sites were available for prices lower than what the port would need to charge to pay for filling and improving land. ${ }^{34}$

\footnotetext{
${ }^{33}$ Committee of Fifteen, "A Report from the Committee of Fifteen on proposed developments at Swan Island.:

${ }^{34}$ Industrial and Port Development Bureau, "Report of the Board of Governors of the City Club."

Planning Documents, COP Archives.
} 
The Oregon Voter, also questioned whether Portland really needed new industrial land, and pointed out that "more than one hundred acres of city property available for industrial sites" were located at the city's St. John's Terminal.

It will not be from a lack of industrial sites at low prices, free from taxation, that industries fail to locate here. ${ }^{35}$

Despite disagreeing on the need for industrial land, the Oregon Voter did not oppose creating more industrial districts and suggested that they should be located close to the city center instead of out in North Portland or on the Columbia Slough. The Voter editorialized that while a "municipal industrial district" there would some day be inevitable, immediate concerns could be met by vacant and "unproductive" land at Guild's Lake and Mock's Bottom. ${ }^{36}$

Committee of Fifteen members agreed that a shortage of land was not the main issue, but returned to their core argument that the city's future prosperity depended on creating special industrial zones that had transportation networks, city utilities, and flood protection.

In the Committee's opinion this repressed growth has not come from a lack of so-called "cheap sites" or "free sites" but is due almost complete lack of "prepared sites" ... a tract of 20 acres or upwards, having the indispensable industrial facilities within striking distance is practically non-existent in Portland, or if so situated to allow them to be availed of at not too great cost and within a short time, then the tract has serious

\footnotetext{
35 “\$25 Per Acre Per Year," Oregon Voter, 17 May 1919, 1;“Impressive Project," Oregon Voter, 10 May 1919, 1.

36 “\$25 Per Acre Per Year," Oregon Voter, 17 May 1919, 1;“Impressive Project," Oregon Voter, 10 May 1919, 1.
} 
defects - unfavorable location, low surface elevation or something as important. ${ }^{37}$

The Committee of Fifteen also advised that an "oversupply of prepared lands" was needed in order to provide potential buyers an adequate selection. ${ }^{38}$

Supporters of the proposed project moved to ease some of their opponents concerns. Just days before the vote, port and dock commissioners pledged not to buy Guild's Lake and Mock's Bottom land or construct any terminal facilities without the approval of port district voters. If voters approved the bill, the consolidated port would, however, move ahead with plans to move the shipping channel. Commissioners asked voters to accept their word that they would issue only limited bonds and to ask the legislature to give district voters approval over future bonds. ${ }^{39}$ The promise convinced the Portland Chamber of Commerce and the Oregon Journal, and both supported the merger bill in the days before the vote. ${ }^{40}$ The Oregon Journal reported:

\begin{abstract}
With almost a complete recession from their former position the majority of the port and dock commissioners ... placed their signatures to a formal pledge ... not to exercise, aside from channel work, the colossal grant of powers contained in the so-called Swan island or port consolidation scheme ... unless the people of the port district by direct vote authorize land purchases and dock construction. ${ }^{41}$
\end{abstract}

\footnotetext{
${ }^{37}$ Committee of Fifteen, "Plans for Waterways, for Terminals and Water Sites 1920," Vol. 2.

${ }^{38}$ Ibid.

39 "Port Bill Pledge for Home Rule, Oregon Journal, 28 October 1920, 1.

40 'Port Arguments Given,' Oregonian, 30 October 1920, 2.

41 "Port Bill Pledge for Home Rule, Oregon Journal, 28 October 1920, 1.
} 
Despite the last minute change, the Committee of Fifteen's merger plan failed to win the support of Oregon voters. City voters, however, did support the plan. In the November 1920 election, Portland voters approved a city charter amendment that would have allowed the transfer of land from the docks commission to the Port of Portland. In addition, Multnomah County voters approved the merger bill, but voters state-wide rejected it. ${ }^{42}$ Committee of Fifteen members blamed "gross misunderstanding" for their plan's failure, saying that "vicious attackers of unknown interest" promoted misconceptions right before the election. Nonetheless, the committee did accept responsibility. The committee admitted that the public might not have understood that many of the details about the industrial district and docks were suggestions, rather than concrete plans.

The report brought many to lose themselves in contemplation of technical details and to forge the big issues involved. At no time did the committee regard any of the engineering features of the project as inflexible or even as essential, except for the proposals for a widened and rectified west channel and the east channel closure. ${ }^{43}$

In his analysis of the vote, MacColl comments that voters outside of the port district probably should not have been allowed to vote on the issue. He argues that if merger supporters had managed to unify Portlanders they might have gotten enough votes in the metropolitan area to "offset the heavy downstate opposition."

\footnotetext{
42 The Port of Portland and the Portland Docks Commission did not merge until 1970.

${ }^{43}$ Committee of Fifteen, "Plans for Waterways, for Terminals and Water Sites 1920," Vol. 2.

${ }^{44}$ MacColl, Growth of a City, 231.
} 
In December 1921, port commissioners went ahead with plans to move the shipping channel to the west side of Swan Island and to dredge it to a thirty-foot depth and 300 -foot width. The port bought Swan Island for $\$ 120,577$. Port commissioners then signed an $\$ 80,000$ contract to sell the Northern Pacific Terminal Company one million cubic yards of river dredge material for filling 7,000 square feet on their Guild's Lake property. ${ }^{45}$ Railroad companies had long been interested in Guild's Lake's submerged lands. In 1906, United Railways bought 200 acres at Guild's Lake with idea that the marsh would be filled and could be used for yards and other rail facilities. A 1908 map shows that the Oregon Railway and Navigation Company (later known as the Oregon-Washington Railway and Navigation Company) and the Northern Pacific Investment Company both owned significant acreage under Guild's Lake. ${ }^{46}$ Railroad executives predicted that Portland's constricted geography would force port and rail developments down river from the city's core. They favored filledin land for development because newly created land had no streets to impede rail lines. ${ }^{47}$ The terminal company was co-owned by the Northern Pacific, the Great Northern, the Oregon-Washington Railway and Navigation Company and the Southern Pacific Railway Company. The companies intended on building a switching yard over Guild's Lake.

\footnotetext{
45 "First Move on Terminal Made," Oregon Journal, 7 December 1921, 1; “Port Buys Swan Island for $\$ 120,577, "$ Oregon Journal, 8 December 1921, 1; "Proposal for filling the Guild's Lake Area with Material to be Dredged from the Channel West of Swan Island," anonymous (the probable author was James B. Kerr), President's Subject Files, GNRC Records, MHS; "New Channel Work Starts Next Month," Oregon Journal, 9 December 1921.

46 "Portland, Oregon," Security Abstract and Trust Company, 1908. This map hangs on the wall of the Rejuvenation Hardware cafe in Portland, Oregon.

${ }^{47}$ B.E. Palmer to J.P. O'Brien, president of the Northern Pacific Terminal Company, 8 October 1921, NPTC, Branch Lines, NPRC Records, MHS.
} 
After the Northern Pacific Terminal Company and the Port of Portland made their deal for depositing dredge spoils, other Guild's Lake landowners organized to negotiate for fill and to privately plan an industrial district. In undertaking the project, property owners faced the same issues that led the Committee of Fifteen to argue for public ownership. Twenty-one properties occupied 788 acres at Guild's Lake and the smaller adjacent Kittredge Lake. Committee of Fifteen engineer George Boschke reported that it would be unlikely that multiple, private owners could cooperate and finance such a comprehensive project:

It will be readily seen that the property so divided and held is not susceptible of being developed economically to its maximum efficiency by private individuals ... when the project is regarded as a whole (it) shall be designed broadly and logically developed as a municipal enterprise, it will materially add to the prosperity of the city and its citizens. ${ }^{48}$

In their efforts, landowners attempted to treat the wetlands' development as a whole. While owners at Mock's Bottom did not make plans to buy dredge spoils, Guild's Lake property owners were "impressed with the value of undertaking a large fill." In early 1922, landowners formed a committee to negotiate and cooperate with the port. As the committee chairman, James B. Kerr publicly represented the Reed Institute, but records show that he also acted as an advisor to the rail companies that owned property in the area. ${ }^{49}$ He was involved with properties co-owned by the Northern Pacific and the Great Northern, including the holdings of the Ruth Realty

\footnotetext{
${ }^{48}$ George W. Boschke, consulting engineer, to The Chairman and Members of Joint Committee of the Port of Portland Commission and The Commission of Public Works of the City of Portland, Oregon, 2 March 1920, President's Subject Files, GNRC Records, MHS.

49 "Property Owners Make Plea for Fill," Oregonian, 14 April 1922.
} 
Company, United Railways, and The Northern Pacific Terminal Company. From 1911 to 1918 , Kerr served as a director and then the chairman of the Ruth Realty Company. He also owned nominal shares in the company, which was originally established by United Railways. Ruth Realty owned forty acres of land on the western edge of the Guild's Lake flood plain that the Lewis and Wiley Hydraulic Company had partially filled in 1914. Kerr and his law partner Charles H. Carey both served as directors of United Railways. Kerr did not hide his private interests in Guild's Lake. In fact, he claimed his interests and the community interests were mutually beneficial. He argued that an industrial district in the area would be good for Portland, and he implied that filling in Guild's Lake would also be a public service because wetlands were unhealthy.

The people of the Port district are not interested alone in the channel but have also a vital concern in providing of the industrial sites and the fact must not be over looked that the filling of these lands subject to periodic overflow involves important considerations of health the sanitation..$^{50}$

Railroad executives commented on Kerr's multiple interests and praised his "ingenuity" in devising an elaborate plan for low and underwater properties to receive low-cost fill from the Port of Portland.

I presume he is interested in two or three ways. I think he is on a committee for the development of Portland's harbor and is also on the Board of Regents of the Reed Institute besides being an attorney for the SP\&S. The underlying and basic principle involved as you will readily gather from the cleverly prepared plan is to take

\footnotetext{
${ }^{50}$ James B. Kerr to Charles Donnelly, president of the Northern Pacific Railway Company, 28 July 1922, President's Subject Files, NPRC Records, MHS.
} 
advantage of the opportunity afforded by this dredging work to get these low-lands filled at a very moderate price. $^{51}$

To mitigate the heavy costs involved in filling wetlands and developing industrial areas, Kerr arranged a favorable price for dredge spoils. In Kerr's plan, landowners would pay the port through land transfers and assessments based on the acreage of the filled property. The land exchange proposal was convoluted, involving land swaps and cash exchanges between property owners, and resulted with the port receiving about forty acres of waterfront land. ${ }^{52}$ In many cases, the property owner deeded a portion of property to the port. Owners did not have to pay cash assessments for ten years. Kerr argued that delayed payments were practical because:

Few if any of the landowners are financially able to make heavy cash payments for reclaiming their property. Furthermore, it is doubtful if the immediate demand for industrial property in this location is at present sufficiently great to justify the landowners in undertaking to meet at once large installment payments based upon an assessment of benefits..$^{53}$

Most property owners approved the deal, which worked out to four cents per cubic yard for the fill - half of what the Northern Pacific Terminal Company had paid in their contract with the port. Owners believed the fill would greatly increase the value of their land. Kerr estimated, for instance, that an unfilled parcel of twelve acres valued at $\$ 22,800$ would nearly double in value to $\$ 41,332$ after being filled. Railroad

\footnotetext{
${ }^{51}$ George Reid to Charles Donnelly, President, 20 July 1922, President's Subject Files, NPRC Records, MHS.

52 "Gift of 40 Acres for Fill Proposed," Oregonian, 4 July 1922, 13.

${ }^{53}$ Anonymous, "Proposal for Filling the Guild's Lake Area with Material to be Dredged from the Channel West of Swan Island," James B. Kerr probable author, President's Subject Files, GNRC Records, MHS.
} 
executives were also impressed. A.R. Cook, assistant engineer of the Northern

Pacific, advised if the railroad did not take this opportunity, filling costs might be five to ten times greater at a later time.

It is not probable that the property can be filled so cheaply as under the present scheme. ${ }^{54}$

Property owners who did not agree to the plan would still get fill, and they would pay more - five cents a cubic yard..$^{55}$ In 1921 the state legislature granted the Port of Portland power to assess owners of low-land properties for filling land without the agreement of the landowner. ${ }^{56}$ Despite this, in practice it is apparent that in some instances the port built bulkheads to keep fill off of non-participant's land.

Kerr maintained that it made geographic and economic sense for the whole area to be filled together because it was a basin surrounded by a railroad berm, on the riverside, and higher land to the south and southwest.

This work involves substantial physical difficulties for the reason that in order to fill to the requisite height of thirty-two feet above low water a dept of fill exceeding twenty seven feet is required and since the expense of bulkheading the fill is prohibitive, large quantities of material slough off before the slope can attain the angle of repose and hence to some extent adjoining owners profit by this work..."

This type of fill overflow had happened in April 1922, when the silt being deposited on Northern Pacific Terminal Company land pushed into neighboring property.

\footnotetext{
${ }^{54}$ A.R. Cook, Principal Assistant Engineer, to H.E. Stevens, Chief Engineer, 7 September 1922, President's Subject Files, NPRC Records, MHS.

${ }^{55}$ Anonymous, "Proposal for Filling the Guild's Lake Area with Material to be Dredged from the Channel West of Swan Island," James B. Kerr probable author.

56 "Reclaimed Lands Will Be Assessed," Oregonian, 27 April 1927, 10.

${ }^{57}$ Anonymous, "Proposal for Filling the Guild's Lake Area with Material to be Dredged from the Channel West of Swan Island," James B. Kerr probable author.
} 
(It) caused the outer crust to give way, creating a great cavern. Simultaneously, ridges of silt emerged above the surface of the water several hundred feet from the shoreline." 58

Workers deposited an additional 500,000 cubic yards of material to fill the sinkhole. ${ }^{59}$

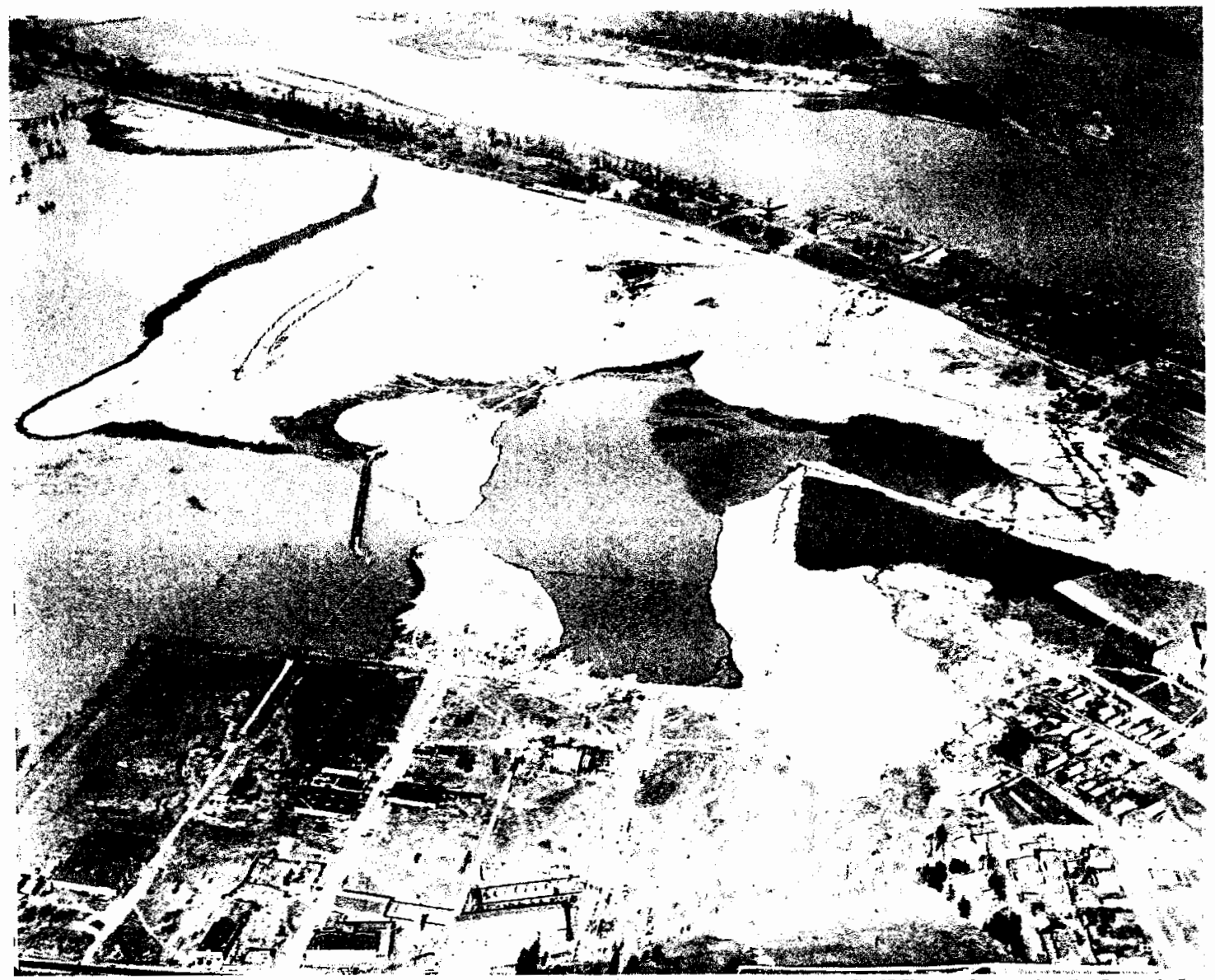

FIGURE 5: This March 1925 photograph shows filling operations at Guild's Lake. The Industrial

Center built by Lewis and Wiley is shown in the grid in the lower left corner. Swan Island can be seen at the top. The smooth gray areas are water and the lighter areas are sand. The city crematory can be seen on the right. The dark triangle of water was left unfilled so that garbage collectors could dump refuse there. Port of Portland Photo Collection, Oregon Historical Society.

\footnotetext{
${ }^{58}$ Memo, "Fill at Guild's Lake," April 1922, President's Subject Files, NPRC Records, MHS. ${ }^{59}$ Ibid.
} 
In March 1922, the port began filling Northern Pacific Terminal Company land. The dredge Tualatin used a thirty-inch suction hose to move river silt from the west channel to the northeast portion of Guild's Lake. In April, the Tualatin transported roughly 700,000 cubic yards of material. The port used 169 life rafts to support the discharge pipeline across the Willamette River. The pipelines went into tunnels under the railroad tracks on berm that separated Guild's Lake from the Willamette River. ${ }^{60}$

In 1923 a second group of Guild's Lake area land owners signed a contract with the port to buy dredge spoils for four cents a square yard. This extended the fill area to include 400 acres between the old industrial district created by Lewis and Wiley to the rail bridge at Bridgeport. This area included Kittredge Lake, which was just northwest of Guild's Lake. Estate managers E.B. MacNaughton and Robert Strong arranged the contract, which also involved land swaps between owners so that the fill could be paid for with waterfront land deeded to the Port of Portland ${ }^{61}$

The nature of wetlands made it difficult for owners to refuse dredge spoils.

Northern Pacific Railway executives weighed their options when filling operations on other properties threatened to cover their tracks.

If we do not agree to permit the port to fill our right of way it will erect a bulkhead on our northerly property line which will leave our track on a level of about six feet below the filled area and would prevent us from getting into the newly created industrial area. ${ }^{62}$

\footnotetext{
60 "Record Established in Dredging Work," Oregonian, 29 April 1922.

61 "Guild's Lake Fill to Boost Portland" Oregonian, 6 August 1923, 18.

${ }^{62}$ Telegram, W. F. Turner to Charles Donnelly and Ralph Budd, 21 May 1924. President's Subject Files, NPRC Records, MHS.
} 
Business owner Oliver Lutz complained that while the port had erected bulkhead around his land, the filling operation pushed water onto formerly dry areas of his property. ${ }^{63}$ Some land owners unsuccessfully resisted filling, including Percy Blyth, who owned twenty-nine acres near the old industrial center and had been active in the hillside development above Guild's Lake. Property owners John Kiernan, who had eleven acres, and the Therkelsen Investment Company, with eleven-and-a-half acres, also tried to block the port from filling their land. ${ }^{64}$

By burying Guild's Lake under hundreds of thousands of cubic yards of river silt, the port and property owners blocked natural water run off from the hillsides. As a result, landslides, drainage problems, and floods damaged property and infrastructure. During the summer of 1923, the city public works department filled a mudslide on Northwest $31^{\text {st }}$ Avenue that rainfall had washed away into Balch Canyon. After that repair, fall and winter rains again washed out the avenue. In the summer of 1924 , the city again made repairs, which again slid out during fall rains. ${ }^{65}$ In 1925 , settling fill broke a sewer pipe that crossed Guild's Lake, and the Oregonian reported it would cost $\$ 90,000$ to repair.

The old lake bed heaved because of the operations ... and thus caused the raising and twisting of the sewer in places. $^{66}$

\footnotetext{
${ }^{63}$ Oliver E. Lutz to Mr. Hampsen, Attorney, 16 February 1926, Guild's Lake Fill, Box 529222, POP archives.

${ }^{64}$ Port of Portland to Mr. Nash, Attorney, 21 January 1924, Box 529229. POP Archives; Port of Portland Assistant Secretary to E. B. MacNaughton, 22 December 1926, Swan Island Airport and Dredging Operations. Box 529228, POP Archives.

${ }^{65}$ John Van Zante to O. Laurgaard, City Engineer, 15 July 1924; H. W. Stone to O. Laurgaard, City Engineer, 29 October 1924, Public Works Administration, COP Archives.

66 "Fill Damages Sewer," Oregonian, 20 December 1925, 33.
} 
The Oregonian reported that human error was not the fault and blamed the damage on "the nature of the fill and the character of the bottom of the lake." Instead of making the repair, the city installed a temporary wooden flume that could be replaced with a more permanent sewer after the port finished pumping fill into the area. ${ }^{68}$ Floods caused problems in 1926, when landslides blocked traffic on St. Helens Road and pooling water damaged electrical equipment at the newly built Guild's Lake rail yard. ${ }^{69}$ In addition, the American Lumber Company -- located in the old industrial center -- claimed damages after fill on neighboring land blocked run off from Balch Canyon, causing water to saturate the ground, form small pools, and overwhelm drains. The port installed an emergency drain. ${ }^{70}$

The port finished filling the first development district at Guild's Lake in 1926, and some property owners then made efforts to build the infrastructure that an industrial district would need. ${ }^{71}$ A number of property owners supported plans for the industrial area, despite the potential for steep costs. Northern Pacific executives were interested.

If the property develops as the promoters of this scheme anticipate there will eventually be some fairly heavy assessments to cover future sewers street improvements, etc., ... which I think is all right as we will also share in

\footnotetext{
${ }^{67}$ Ibid.

68 " $\$ 375,000$ Sewer Need Stressed," Oregonian, 16 December 1930, 1.

69 " $\$ 375,000$ Sewer Need Stressed," Oregonian, 16 December 1930, 1; Mr. LaRoche, Attorney, to Port of Portland, 22 September 1926. Box 529229, POP Archives.

${ }^{70}$ Memo, "Claim for Damages at the American Lumber and Box Company," 8 April 1926. Box 529229, POP Archives.

${ }^{71}$ Port of Portland Assistant Secretary to E. B. MacNaughton, 22 December 1926, Swan Island Airport and Dredging Operations, Box 529228, POP Archives.
} 
the benefits which would follow from a general improvement of the property. ${ }^{72}$

Property owners John Yeon, Emery Olmstead, B. E. Palmer and Gwilym Jones joined with estate manager Robert Strong in leading the Guild's Lake Development Association. They asked the nearly seventy landowners in the area to contribute about a half of one percent of their property value so the association could hire an engineer to plot out streets, railroads, and utilities.

No individual owner can properly plat his land until the broader aspects of the problem have been solved.... The committee regards this development project as the most important now under consideration in Portland and trusts that you will approve of the scheme advanced ... by extending it your fullest support and financial aid. ${ }^{\mathfrak{7}}$

The Port of Portland supported development plans and contributed \$985. With holdings valued at $\$ 246,000$, the port had become a large property owner in the Guild's Lake area after receiving land in exchange for dredge spoils. The Guild's Lake Development Association hired Robert Dieck, who had also done work for the Committee of Fifteen, and planned to submit his report to the city council for approval. ${ }^{74}$ Plans stalled, however, and the association had difficulty convincing property owners to cooperate.

The association tried to convince property owners that working together was in their best interest, but many refused to cooperate or did not reply to association

\footnotetext{
${ }^{72}$ H.E. Stevens, Chief Engineer, to Charles Donnelly, President, 12 September 1922, President's Subject Files, NPRC Records, MHS.

${ }^{73}$ Guild's Lake Development Association to the Port of Portland, 6 August 1926, Box 29228, POP Archives.

74 "Port to do Share in Guild District," Oregonian, 14 August 1926; "Guilds Lake Tract Brings $\$ 1,800,000$," Oregonian, 5 October 1926, 1 .
} 
communications. Non-compliant owners included some who had also resisted filling, like Percy Blyth and John Kiernan, both of whom eventually had to pay the port for the fill with portion of their property. ${ }^{75}$ By 1928 , the association had not made progress. The district needed a sewer system before owners could implement development plans, however, the city had been unable to get owners to pay property tax assessments for the sewer. After they rejected city engineer Olaf Laurgaard's plants to build a $\$ 600,000$ sewer, Laurgaard proposed a $\$ 375,000$ sewer to replace the inadequate rotting wooden flume. Laurgaard told property owners that the flume had been a temporary measure to protect property from surface water. He told property owners that they needed to provide drainage for Balch Creek because filling Guild's Lake had eradicated the natural outlet. ${ }^{76}$ Apparently property owners could not organize, however, because seven years later a sewer had not been built the decrepit wooden flume was still in use. ${ }^{\pi}$

In 1929, the Guild's Lake industrial area was still more of a vision than a reality. The port had pumped twenty-five million cubic yards of river silt into the area, filling 1300 acres of land. Nine-hundred acres of that was yet to be developed. Assessors claimed the land had become more valuable, with the area's total worth increasing from $\$ 1.25$ million in 1922 to $\$ 5$ million in 1928 . Some industries had

\footnotetext{
${ }^{75}$ Guild's Lake Development Association to Members, 14 November 1927. Guilds Lake, 1921-1927, Box 529228, POP Archives; Robert G. Dieck, Consulting Civil Engineer, to the Committee on Arrangements at Guilds Lake. Box 529228, POP Archives; Deeds, Port Lands Acquisition Property, 1921-1939, Box 529222, POP Archives; "Financial Arrangement of the Guild's Lake Development Association," March 1928. Port Land Acquisition Property, 1921-1939, Box. 529222, POP Archives. 76 "Plans for Guild's Asked," Oregonian, 11 May 1929, 20; "\$375,000 Sewer Need Stressed," Oregonian, 16 December 1930, 1.

$\pi$ "Engineer Clears Guild's Lake Case," Oregonian, 17 December 1937, 11.
} 
moved in, including the Paper Maker's Chemical Company and the Soule Steel Company, however, there was little demand for industrial land. Furthermore, in Growth of a City, MacColl found that a few property owners could not or did not pay for the increased property taxes, and, as a result, lost their property. He speculates that the port filled the land long before it was actually needed for industries. The onset of the Depression prolonged the inactivity, and owners were not able to establish an industrial district at Guild's Lake for many years. ${ }^{78}$ During World War II, the Housing Authority of Portland used the area to house the influx of workers to Portland's shipbuilding industry. Industries finally moved into the area in the 1950s.

\footnotetext{
${ }^{78}$ Day and Zimmerman of Philadelphia for the Chamber of Commerce, "Industrial Activity and Resources of the Proposed Establishment of an Industrial District in Portland."1930. Port Land Acquisition Property, 1921-1939, Box. 529222, POP Archives; "Guilds Lake Land Becoming Valuable," Oregonian, 6 October 1929, sect. 2, p.1; MacColl, Growth of a City, 237-251.
} 


\section{Conclusion}

\section{Culture and Environment Build Landscapes}

Today the curve of St. Helens Road in northwest Portland skirts the edge of a non-existent shoreline, providing an echo for the marshy 250 -acre lake that was once there. Otherwise, the area's built environment offers very few hints of its watery past. The Portland Terminal Company's "lake yard" dominates the northern portion of the filled lake, and an extended shoreline reaches into the Willamette River. Pavement and buildings for factories and warehouses stretch south of the rail yard. Some of the buildings date back to the late 1940 s, when people were finally able to build industries at Guild's Lake, twenty years after Port of Portland dredges finished pumping in river sand. In 1930, the year this narrative closes, nearly the entirety of the filled lake was a sandy wasteland, dotted with scrubby foliage. This realty was quite different from the visions that drove efforts to create an industrial district. From the time that organizers chose Guild's Lake for the 1905 Lewis and Clark Exposition and Oriental Fair, people used their imaginations to see what they wanted to replace the marshy wetlands. They saw Guild's Lake as a blank slate, and envisioned dry land for an industrial district that seemed to promise both personal profits and benefits for the city. City leaders and property owners did not value Guild's Lake as it was - a shallow, reedy body of water that flowed with seasonal rains and ebbed during summer droughts.

Attitudes about wetlands affected developers' plans for Guild's Lake. In the early twentieth century, Portlanders generally held negative views of wetlands. They inherited the belief that swamps and marshes were unhealthy and chaotic. Early 
Portlanders rarely saw the beauty in the city's natural wetlands, but instead considered them wasted and useless places. Although most city residents appreciated the beauty of Guild's Lake during the 1905 Lewis and Clark Exposition, that appreciation was based more on fantasy than reality. During the fair, engineers pumped river water into Guild's Lake to make it more like a lake, and less like a marsh. The grandeur of the fairgrounds convinced some people that the area should be preserved as a city park. The idea was short-lived, however, and failed to win city-wide support. When the fair ended, receding water exposed muddy bottomlands at Guild's Lake and interest in preserving the area plummeted.

Portlanders abused wetlands, and, as a result, found them even less appealing. Neighbors of Hawthorne Springs polluted the water with raw sewage, contributing to an outbreak of typhoid fever and spoiling city plans for a park there. People also threw their trash into wetlands, burying them under sawdust and household refuse. Portlanders eventually used dirt to fill in most of the urban wetlands and the Willamette River's marshy edges. City builders saw sloughs, marshes, and creeks as barriers to city growth. Throughout world history, people have commonly drained and buried wetlands and shorelines for urban expansion. Portland was not unusual. Founders established the city in an area bound by steep hills and the Willamette River. People eked out more space on both sides of the river by burying many wetlands. Growth pressures and real estate values motivated landowners and developers. Many of Portland's upper classes had acquired part of their wealth through real estate speculation. Buying submerged land at Guild's Lake may have been a gamble, but 
some people trusted that there would come a time that increased land values would justify the expense of filling the lake.

People wanted to fill Guild's Lake because they did not value wetlands, but topography also played a role. In 1904, mining entrepreneur Lafe Pence visited Portland and went to see the future Lewis and Clark Exposition fairgrounds. He later said he was greatly impressed by the topography of Guild's Lake and the adjacent hillsides. To him, the creeks, steep hills, and flat marshland suggested a giant placer mine. He saw that he could use Balch Creek and other waters to sluice the hills into the lake. He claimed that Guild's Lake was the perfect "dump." He dreamed of creating an upscale view neighborhood and also solid ground for factories, warehouses and rail yards. The existing landforms suggested potential uses to Pence, and mining technology made his vision a possibility. Dry grading could cost between twenty and forty cents for the removal of each cubic yard. Pence offered to blast dirt away with high-powered hoses for five to seven cents a cubic yard. He could then sell that fill to landowners at Guild's Lake.

Pence's scheme highlighted tensions between private aims and public benefits that were a common thread through all plans to fill Guild's Lake. During the first phase of the filling, between 1905 and 1914, the arguments were more about the affects of hydraulic sluicing at a nearby park than a public vision for the area. The city was not a participant in Pence's plan because it involved private property and private development. City planning was not yet a factor in Portland, so developers did not need any kind of public approval. The city only became involved when Pence's 
operations threatened public property. From the start, Pence threatened Macleay Park. He claimed Balch Creek waters and slashed a swath through the park for his flumes. He also threatened the park by washing away adjacent property. Portland leaders had only recently begun an ambitious park-building plan. They considered Macleay Park to be a public treasure, and picnickers went there frequently. Parks Board President Leander Hawkins tried to fight Pence's use of the creek and his illegal incursions onto park property. Other city leaders also wanted to protect the park. They urged the parks board to deny Pence a throughway permit. Members of the Chamber of Commerce recommended denial, but then changed their minds -- deciding that Pence's work represented progress that would benefit private and public interests. Mayor Harry Lane went through the same reversal of opinion. When he discovered that Pence had illegally trespassed in Macleay Park, he ordered police to destroy the flume. However, the next day he said he would always support efforts to bring capital and development to the city. Members of the Chamber of Commerce and Mayor Lane had to weigh conflicting values. The debates over Macleay Park showed that many Portlanders valued saving "wild" places inside of parks, and revealed that some people were skeptical of the value of Pence's hydraulic operations and land alterations. However, the capitulation of community leaders toward Pence shows that many city officials, businessmen, and landowners valued Guild's Lake area land primarily as property - property that could be "improved" and sold at a profit. In order to shore up support, Pence played up the supposed benefits his project would bring to Portland. He offered "his" Balch Creek water for use at the Lewis and Clark Exposition and 
talked about attractive hillside homes and a new area for industries. He argued that he would improve the city's landscape by transforming "useless" land.

After Pence's business failed and he left town, the Lewis and Wiley Hydraulic Company took over the project. They did not get the headlines the way Pence had, but they also struggled with conflicting cultural values. In addition, they weighed private versus public interests. William Lewis and Charles Wiley aspired to the ideals of City Beautiful by hiring John Olmsted to design their hillside neighborhood, Westover Terraces. Like Pence, they also planned to use sluice spoils to fill in property at Guild's Lake. Despite their goal of building "one of the most attractive resident districts" in America, economic realities caused Lewis and Wiley to scale back their plans. Although they claimed they would follow the exacting details of Olmsted's plan, they changed their minds and hired a local engineer to fit in more lots by redesigning the development with smaller lot sizes and narrower streets. In addition, Macleay Park again became an issue pitting the potential for private gain against a public benefit. Lewis and Wiley owned Balch Canyon north of Macleay Park. They considered filling the canyon to the height of the Thurman Street Bridge to build more home lots. City residents, however, wanted the land to be included into the park. Lewis and Wiley eventually decided to negotiate with the city to sell them the land. In 1914, Lewis and Wiley finished their project, but the endeavor was not financially successful. Like Pence, they were in debt and unable to fulfill all of their contracts for filling marshland. Pence and the Lewis and Wiley Company only managed to fill in about one-fifth of Guild's Lake. It is likely that much of the dirt deposited sloughed 
off and settled over a dispersed area, as happened later when the port was filling Northern Pacific Terminal Company land.

The fluid nature of Guild's Lake directed human choices and actions. Submerged lands presented a challenge to development and landowners realized that they needed to work cooperatively to fill their property. They also needed to consider wetlands properties together, rather than as individual parcels. People began to consider the Guild's Lake area as a whole landscape during the Lewis and Clark Exposition, however, it wasn't until the late 1910s that collective action dominated efforts to alter Guild's Lake.

The emergence of urban planning in Portland led to discussions between business leaders and city and port officials about zoning and improving the Willamette River for shipping. The mayor appointed a Committee of Fifteen men to study how the Portland Docks Commission and Port of Portland might improve Portland's harbor and create industrial zones. They produced a plan that promised to radically change a large landscape, which included Guild's Lake. Again, nature played a role by suggesting possibilities and directing human approaches to landscape change. The port wanted to dredge a new shipping channel on the west side of Swan Island, and 1,500 acres of wetlands were immediately available for deposits of dredge spoils. The Committee of Fifteen produced a plan that called for a port and docks commissions merger, which would give the port the ability to own, develop, lease, and sell industrial land. Committee members recommended the port then buy Swan Island, 
Guild's Lake, and Mock's Bottom so that it could transform the entire area into a large public landscape that could meet a number of business and trade needs.

This second phase of filling at Guild's Lake brought up several different types of pubic versus private issues. Looking at if from a sociological perspective, one might question whether all Portlanders would have benefited from the proposed public landscape. Richard Foglesong's work on the history of planning reveals that although business leaders claimed they were working for the public good, the changes they suggested, would have mostly benefited themselves. The Committee of Fifteen plan offered economic promise to factory owners, bankers, and real estate speculators, who wanted increased trade, better transportation facilities, and more investment possibilities. When Committee of Fifteen member Fred Knapp declared that, "We want smokestacks and not swamps," he was speaking as a member of the elite business class in Portland. Of course, some committee members also dealt with a more direct conflict of interests. As appointed representatives of the city, a few members, including James Kerr and Emery Olmstead, suggested large public expenditures and landscape alterations that could bring personal financial benefits. After the Committee of Fifteen failed to win public support for their plan, landowners at Guild's Lake moved ahead with their own plans to create an industrial district. They cooperated to purchase inexpensive dredge spoils from the Port of Portland, but were unable to work together to create an industrial district. Guild's Lake Development Association leaders and Portland city officials could not convince enough property owners to contribute financially toward a development plan and 
infrastructure amenities. The lack of a sewer system, and landowner's disinterest in paying for one, blocked industrial developments. In the end, private landowners were unable to work collectively to create their desired landscape. For many years, most of the Guild's Lake industrial area was vacant land, plagued with drainage and flooding issues.

Because the intended industrial development came much later, this story is more about vision than results. In the process of landscape creation at Guild's lake, people revealed their values. Tensions arose over private development and public spaces. People sometimes struggled with their own priorities, pitting ideals against profits and supposed city benefits. Over time, development plans reflected changing values. For example, public planning was nonexistent during the early filling, but was instrumental during the later filling. Cultural perceptions and the existing environment both influenced the plans that people made for Guild's Lake. Nature played a role in two ways - first through suggestion and secondly by restricting human action. People interpreted the landforms at Guild's Lake through cultural lenses. They saw a useless lowland that was serendipitously close to steep hills and the Willamette River. They believed that with engineering and technology they could reshape the topography by moving dirt from the hills, and later from the river, into Guild's Lake. After early efforts to fill the lake failed, however, developers realized they needed to work cooperatively. The realities of the environment at Guild's Lake pushed landowners to work with the city and the Port of Portland. Nature shaped 
human action. Today, Guild's Lake is gone, but it is still evident as an ingredient of the modern landscape. 


\section{References}

\section{Primary}

\section{Collections}

City of Portland Archives

Library of Congress

Minnesota Historical Society

Northern Pacific Railway Company Records

Great Northern Railway Company Records

Multnomah County Records

Oregon Historical Society

Port of Portland Archives

\section{Manuscript Materials}

Olmsted, John. Report of the Lewis and Clark Exposition. Papers of the Olmsted Associates, Reel 91, Library of Congress.

Olmsted, John. Lewis and Wiley Subdivision, Papers of the Olmsted Associates, Reel 223, Library of Congress.

"Proceedings of the $1^{\text {st }}$ Annual Convention of the Northwest Rivers and Harbors Congress, Oct. 4-6, 1920." Government Records, Port of Portland, Oregon Historical Society.

\section{Government Documents}

Beckham, Stephen Dow. "Historical Assessment: Westside CSO Tunnel Shafts, Pump Station, and Pipeline Project." Memo, Stephen Dow Beckham to ParsonsBrinkerhoff, 15 February 2001; Foundation Engineering Inc., "Preliminary Geologic Assessment: Westside CSO Tunnel Project." Portland, 17 July 2000. 
. "Eastside of Willamette River, Portland Oregon: Historical

Investigations for the Eastside Consolidated Sewer Overflow (CSO)

Project." Portland: City of Portland, Bureau of Environmental Services, September 2003.

Bennett, Edward H. The Greater Portland Plan. Portland, Oregon, 1912.

Planning Documents, City of Porltand Archives.

Cheney, Charles. Report to the City Planning Commission. Portland, June 1919. Planning Documents, City of Portland Archives.

Foundation Engineering, Inc., "Preliminary Geologic Assessment," West side Combined Sewer Overflow Tunnel Project, City of Portland, July 17, 2000.

Mische, E.T. Report to the Parks Board, 3 December 1909, Council Documents - Parks, City of Portland Archives.

Olmsted, John. Report of the Park Board. Olmsted Associates, Parks Department, City of Portland Archives.

\section{Newspapers}

Oregonian

Oregon Journal

Portland Daily News

The Oregon Voter

\section{Internet}

Bureau of Municipal Research New York City, "Organization and Business Methods of The City Government of Portland, Oregon," 1913. This document can be found online at www.nalga.org/confer/toronto/materials/Portland1913.pdf.

Bureau of Planning, "Adopted Guild's Lake Industrial Sanctuary Plan," Portland, Oregon, 2005. http://www.portlandonline.com/planning/index.cfm?c=34289. 
Environmental Protection Agency, "EPA Proposes No Further Action for Gould Groundwater," Portland, Oregon, August 2002, http://yosemite.epa.gov/R10/CLEANUP.NSF/7d19cd587dffleee8825685f 007d56b7/90a98d27ff0206af8825651a00598ed2! OpenDocument, (September 2004).

Portland Bureau of Environmental Services, "Willamette Watershed Characterization Report: Balch Subwatershed, and Kittredge Subwatershed," http://www.portlandonline.com/bes/index.cfm?c=31819, (September 2004).

Portland Bureau of Environmental Services, "Willamette Watershed Characterization Report: Balch Subwatershed, Plant Communities," 2004, http://www.portlandonline.com/bes/index.cfm?c=31819, (September 2004).

Portland Bureau of Environmental Services, "Willamette Watershed Characterization Report: Balch Subwatershed, Wildlife Communities, 2004, http://www.portlandonline.com/bes/index.cfm?c=31819, (September 2004).

\section{Secondary Sources}

\section{Books}

Abbott, Carl. The Great Extravaganza: Portland and the Lewis and Clark Exposition. Portland: Oregon Historical Society, 1981.

--------. Portland: Planning, Politics, and Growth in a Twentieth-Century City. Lincoln and London: University of Nebraska Press, 1983.

Anderson, David P. Field Guild to Oaks Bottom. Portland: Audubon Society of Portland, 1979.

Atkins, Peter, Ian Simmons and Brian Roberts, People, Land and Time: an historical introduction to the relations between landscape, culture and environment. London and New York: Arnold, 1998.

Botkin, Daniel. Discordant Harmonies: A New Ecology for the Twenty-first Century. New York and Oxford: Oxford University Press, 1990. 
Boyd, Robert. The Coming Spirit of Pestilence: Introduced Infectious Disease and Population Decline among Northwest Coast Indians, 1774-1874. Seattle and London: University of Washington Press, 1999.

Foglesong, Richard. Planning the Capitalist City: The Colonial Era to the 1920s. Princeton; Princeton University Press, 1986.

Hudson, Brian J. Cities on the Shore: The Urban Littoral Frontier. London: Pinter, 1996.

Humphreys, Margaret. Malaria: Poverty, Race, and Public Health in the United States. Baltimore and London: The Johns Hopkins University Press, 2001.

Hurd, Richard M. Principles of City Land Values. New York: The Record and Guide, 1903. Reprint, New York: Arno Press and the New York Times, 1970 .

Hurley, Andrew, editor. Common Fields: An Environmental History of St. Louis. St. Louis: Missouri Historical Society Press, 1997.

Kennedy, Lawrence W. Planning the City upon a Hill: Boston since 1630. Amherst: The University of Massachusetts Press, 1992.

Johnson, Robert. The Radical Middle Class: Populist Democracy and the Question of Capitalism in Progressive Era Portland, Oregon. Princeton and Oxford: Princeton University Press, 2003.

Lansing, Jewel. Portland: People, Politics, and Power 1851-2001. Corvallis: Oregon State University Press, 2003.

Maccoll, E. Kimbark and Stein, Harry H. Merchants, Money, and Power: The Portland Establishment, 1843-1913. Portland: The Georgian Press, 1988.

-.-. The growth of a city: power and politics in Portland, Oregon, 1915-1950. Portland, Oregon: Georgian Press, 1979.

--.-.-.-. The Shaping of a City: Business and Politics in Portland, Oregon 1885-1915. Portland: The Georgian Press Company, 1976.

Meinig, D.W. The Interpretation of Ordinary Landscapes: Geographical Essays. New York and Oxford: Oxford University Press, 1979. 
Melosi, Martin V. Effluent America: Cities, Industry, Energy, and the Environment. Pittsburgh: University of Pittsburgh Press, 2001.

Merchant, Carolyn. Ecological Revolutions: Nature, Gender, and Science in New England. Chapel Hill and London: The University of North Carolina Press, 1989.

Norwich, John Julius. A History of Venice, New York: Vintage Books, 1989.

Rose, Carol M. Property and Persuasion: Essays on the History, Theory, and Rhetoric of Ownership. Boulder, San Francisco, and Oxford: Westview Press, 1994.

Snyder, Eugene E. We Claimed This Land: Portland's Pioneer Settlers. Portland: Binford \& Mort Publishing, 1989.

Steinberg, Theodore. Slide Mountain, or The Folly of Owning Nature. Berkeley, Los Angeles, and London: University of California Press, 1995.

Tarr, Joel A. In Search of the Ultimate Sink: Urban Pollution in Historical Perspective. Akron, Ohio: University of Akron Press, 1996.

U.S. Army Engineer, District, Portland Corps of Engineers, The History of the Portland District Corps of Engineers, 1871-1969. Portland, Oregon, 1970.

White, Richard. The Organic Machine. New York: Hill and Wang, 1995.

Vileisis, Ann. Discovering the Unknown Landscape: A History of America's Wetlands. Washington D.C. and Covelo, Calif.: Island Press, 1997.

\section{Articles}

Cronon, William. "A Place for Stories: Nature, History, and Narrative." Journal of American History, 78:4 (March, 1992).

Flores Dan. "Place: An Argument for Bioregional History" in Northwest Lands, Northwest Peoples: Readings in Environmental History, edited by Dale D. Goble and Paul W. Hirt, 31-50. Seattle and London: University of Washington Press, 1999.

Sauer, Carl. "The Morphology of Landscape." Land and Life: A Selection from the Writings of Carl Ortwin Sauer, edited by John Leighly, 315-350. Berkeley and Los Angeles: University of California Press, 1965. 


\section{Theses and Dissertations}

Klingle, Matthew William. "Urban by Nature: An environmental history of Seattle, 1880-1970." Ph.D. diss., University of Washington, 2001.

Guzowsky, Kenneth James. "Portland's Olmsted Vision (1897-1915): A study of the public landscapes designed by Emanuel T. Mische in Portland, Oregon." Master's thesis, University of Oregon, 1990.

\section{Internet}

"Hill, James Jerome (1838-1916)," The Online Encyclopedia of Washington State History, HistoryLink.org, http://www.historylink.org/essays/output.cfm?file_id=7294 (6 October 2005);

Portland Parks and Recreation. "Historic Timeline," http://www.portlandparks.orlg/History/History_1852-1900.htm, and http://www.portlandparks.org/History/History_1901-1920.htm (24 January 2005),

Portland State University, "Wapato Bog to Industrial Sanctuary: The Transformation of Portland's Guild's Lake," 2004, http://www.history.pdx.edu/guildslake/, (27 January 2005).

Toll, William. "Commerce, Climate \& Community: a History of Portland \& its People," Oregon History Project, Oregon Historical Society, http://www.ohs.org/education/oregonhistory/narratives/index, (27 January 2005). 